Article

\title{
Detection and Validation of Tropical Peatland Flaming and Smouldering Using Landsat-8 SWIR and TIRS Bands
}

\author{
Parwati Sofan ${ }^{1,2, *(\mathbb{D})}$, David Bruce ${ }^{3}$, Eriita Jones ${ }^{4}$ and Jackie Marsden ${ }^{5}$ \\ 1 PhD Candidate, University of South Australia (UniSA), Adelaide, SA 5000, Australia \\ 2 Remote Sensing Application Center of Indonesian Institute of Aeronautics and Space (LAPAN), \\ Jakarta 13710, Indonesia \\ 3 Natural and Built Environments Research Centre, University of South Australia, Adelaide, SA 5000, \\ Australia; david.bruce@unisa.edu.au \\ 4 Computational Learning Systems Laboratory, School of IT and Mathematical Sciences, \\ University of South Australia, Mawson Lakes, SA 5095, Australia; eriita.jones@unisa.edu.au \\ 5 Imagery, Landgate, Midland, WA 6056, Australia; Jackie.Marsden@landgate.wa.gov.au \\ * Correspondence: parwati.sofan@mymail.unisa.edu.au
}

Received: 24 January 2019; Accepted: 19 February 2019; Published: 24 February 2019

check for updates

\begin{abstract}
A Tropical Peatland Combustion Algorithm (ToPeCAl) was first established from Landsat- 8 images acquired in 2015, which were used to detect peatland combustion in flaming and smouldering stages. Detection of smouldering combustion from space remains a challenge due to its low temperature and generally small spatial extent. The ToPeCAl consists of the Shortwave Infrared Combustion Index based on reflectance $\left(\mathrm{SICI}_{\rho}\right)$, and Top of Atmosphere (TOA) reflectance in Shortwave Infrared band-7 (SWIR-2), TOA brightness temperature of Thermal Infrared band-10 (TIR-1), and TOA reflectance of band-1, the Landsat- 8 aerosol band. The implementation of ToPeCAl was then validated using terrestrial and aerial images (helicopter and drone) collected during fieldwork in Central Kalimantan, Indonesia in the 2018 fire season, on the same day as Landsat- 8 overpasses. The overall accuracy of ToPeCAl was found to be $82 \%$ with omission errors in a small area (less than $30 \mathrm{~m} \times 30 \mathrm{~m}$ ) from mixtures of smouldering and vegetation pixels, and commission errors (with minimum area of $30 \mathrm{~m} \times 30 \mathrm{~m}$ ) on high reflective building rooftops in urban areas. These errors were further reduced by masking and removing urban areas prior to analysis using landuse Geographic Information System (GIS) data; improving the overall mapping accuracy to 93\%. For comparison, the day and night-time VIIRS ( $375 \mathrm{~m}$ ) active fire product (VNP14IMG) was utilised, obtaining a lower probability of fire detection of $71 \%$ compared to ground truth, and $57-72 \%$ agreement in a buffer distance of $375 \mathrm{~m}$ to $1500 \mathrm{~m}$ when compared to the Landsat- $8 \mathrm{ToPeCAl}$ results. The night-time data of VNP14IMG was found to have a better correspondence with ToPeCAl results from Landsat 8 than day-time data. This finding could lead to a potential merger of ToPeCAl with VNP14IMG to fill the temporal gaps of peatland fire information when using Landsat. However, the VNP14IMG product exhibited overestimation compared with the results of ToPeCAl applied to Landsat-8.
\end{abstract}

Keywords: smouldering; flaming; peatland; tropical; Landsat-8; SWIR; TIR; ToPeCAl; VIIRS; VNP14IMG; validation; ground truth

\section{Introduction}

Wildfire is a global issue which threatens every year during dry seasons. For almost two decades, forest/land fires have attracted both interest and challenge for research to provide a useful monitoring 
system from satellite remote sensing data [1-3]. Tropical peatland fire is one type of forest/land fire which remains a challenge in providing a fire detection algorithm, due to the characteristics of tropical peat, its terrestrial environment and tropical atmospheres.

Approximately $47 \%$ of global tropical peatlands exist in Indonesia. These peatlands were formed as spacious domes that consist of the woody and partly decomposed remains of rainforest trees (branches, leaves, roots and trunks). These domes sustain a peat swamp forest that encompass large areas of lowland landscape between major rivers $[4,5]$. Under undisturbed conditions, the Indonesian peatland store about $57.4 \mathrm{Gt}$ of Carbon, or $65 \%$ of the total global tropical peatland Carbon $[4,5]$. However, large areas of tropical peatlands in Indonesia have been degraded due to slash and burn activities for development of plantations such as oil palms, rubber, and pulp trees, and for food production [6,7]. In 2015, the forest and peatland fires in Indonesia caused a total economic loss of about USD 16 billion and emitted $1.75 \mathrm{Gt}$ of Carbon into the atmosphere [8]. Although the Indonesian government has declared a zero burning law for land clearance (Law No.32/2009), the Peatland Conversion Moratorium (23 October 2015) and the Peatland Restoration Agency establishment (January 2016), slash and burn activity is still regularly used for land preparation, as it has an economic benefit to farmer groups, given the continuing market demand for illegal land for plantations [9].

A large coverage in near real-time observation of forest/land fire can be obtained freely from the coarse spatial resolution of satellite sensors such as Geostationary Operational Environmental Satellite System, Meteosat Second Generation-Spinning Enhanced Visible and Infrared Imager, Advanced Very High Resolution Radiometer, Moderate Resolution Imaging Spectroradiometer (MODIS), Visible Infrared Imaging Radiometer Suite (VIIRS), and Advance Himawari Imager [2,3,10-16]. Among them, the MODIS and VIIRS active fire products have been used by the Indonesian Disaster Management Agency (BNPB) for guidance in monitoring forest/land fires in the field. According to the local BNPB in Central Kalimantan, Indonesia, most of the peatland fires found in the field were in flaming stages [17]. The properties of smouldering peat fire, which generates a lower radiance intensity and a lower temperature than flaming [18], as well as the coarse spatial resolution likely explain why smouldering fires are often not detected by the above-mentioned satellite fire detection products $[19,20]$. Significant smoke generated during fire events and cloud cover can also obscure fire detection [21,22]. Other than that, smouldering peat fire often occurs in small areas with low spread rates which, if left unattended, can extend into large areas $[18,23,24]$. However, smouldering peat fire releases higher concentrations and particulate carbon emissions, such as carbon monoxide and methane, than peat in a flaming state [25] and also produces larger particles than other fuels [26]. Thus, it is important to know the location of the smouldering peat fires so that suppression occurs before extension into a larger area and to minimise damaging emissions.

Most of the global operational fire products from low spatial resolution satellite data $(\sim 1 \mathrm{~km}$ pixel size) use the 3-4 $\mu \mathrm{m}$ (middle infrared (MIR)) and the 10-11 $\mu \mathrm{m}$ (thermal infrared (TIR)) components of the electromagnetic spectrum to detect smouldering and flaming fires, which operate at temperatures from 400 to $1200 \mathrm{~K}[27,28]$. However, small and smouldering fires are often undetectable in low spatial resolution data such as MODIS $[19,20]$. The higher the spatial resolution of the satellite sensor the greater the portion of fire area that can be detected [29]. Research in the United States of America showed the minimum fire area detectable by MODIS was 105 ha [19]. The small satellite Hot Spot Recognition System-Bi spectral Infra-Red Detector, with its $370 \mathrm{~m}$ pixel size, successfully detects smouldering and flaming by estimating fire temperature in Central Kalimantan's peatland with a minimum fire area of 0.15 ha [30]. The other small satellite, which is a product of German Aerospace Center (DLR) FireBird Mission, is the Technology Experiment Carrier-1 (TET-1), with a $160 \mathrm{~m}$ spatial resolution; detects a minimum fire area of 0.01 ha at temperatures at $500 \mathrm{~K}$ or 1 ha at $450 \mathrm{~K}$ (smouldering), with a repeated observation of 2-3 days [31]. The MIR sensor of TET- 1 has a high-temperature saturation up to $900 \mathrm{~K}$, which is able to detect peat fire through smoke and haze [32]. However, TET-1 data capture on a regular basis is not operational and a specific request to DLR needs to be made for data over a certain region is required. Therefore, there is a need for accurate 
low-temperature smouldering fire detection in low cost or open-access high temporal frequency imagery with sufficiently small spatial resolution. In the moderate spatial resolution area (30 and $100 \mathrm{~m}$ pixels) and repeated observation of 16 days, sensors such us Advanced Space-borne Thermal Emission and Reflection Radiometer (ASTER) and Landsat-8 possibly could be used to detect flaming and smouldering peatland. ASTER has a higher temperature saturation than Landsat-8; however, ASTER is an on-demand instrument which means that data capture over a specific region on a regular basis is difficult to achieve. This is unlike Landsat-8 $[33,34]$ which provides regular coverage (cloud permitting). Fire detection with ASTER data mainly employs the shortwave infrared (SWIR) band and near infrared band for eliminating bright objects [34] and is utilised mainly for validation of the lower spatial resolution products from other sensors, due to its high-temperature saturation and finer spatial resolution [2,34-38].

Instead of MIR data that are available in a lower spatial resolution sensor, the current Landsat-8 moderate spatial resolution sensor, Operational Land Imager (OLI) and Thermal Infrared Sensor (TIRS) provide hot target detection (flaming fires) using SWIR at 1.6 and $2.2 \mu \mathrm{m}[29,39]$. Moreover, from hyperspectral data, the SWIR spectra at 2.061 and $2.429 \mu \mathrm{m}$ were able to be used to detect flaming fire [40]. Meanwhile, [41] detected smouldering fires detection via the use of longwave thermal infrared spectra and the implementation of Planck's radiation law, enabling estimation of fire temperature within a minimum area range of $40-90 \mathrm{~m}^{2}$ using Landsat- 8 night-time data with limited atmospheric disturbance and no sun radiation effects on fire temperature estimation; however Landsat- 8 night-time data is also not operationally available like day-time data. Thus, smouldering peat fire detection during day-time needs to be explored. A recent active fire detection algorithm for global application of Landsat-8 day-time data was developed by Kumar and Roy [42] using the SWIR and red reflectance bands and compared with other fire algorithms developed from Landsat- 8 data $[29,39]$. They revealed that the most significant underestimation of all three algorithms were found to be in Indonesian peat fires. Additionally, atmospheric issues may interfere with peat fire detection; in the dry season, most peat fires occur with very smoky conditions, thereby increasing the difficulty of satellite image interpretation, which has not been considered in previous research.

This study explores how flaming and smouldering of tropical peat fires, with a variety of atmospheric states (clear and smoke conditions) can be detected from the SWIR and TIR of Landsat- 8 day-time data. Although the Landsat- 8 day-time data is only available every 16 days, it still is very useful considering the fact that smouldering peat fire can occur from days to months depending on natural extinguishment from rainfall, or firefighting efforts. In 2015, smouldering fires lasted about six months in Central Kalimantan and South Sumatera. Additionally, a peatland combustion algorithm detection based on Landsat- 8 data may be able to be applied to other satellite sensors such VIIRS with a lower spatial resolution $(375 \mathrm{~m})$, but higher temporal resolution (1-2 times per-day). Thus, the temporal gaps of peatland fire monitoring from a medium spatial resolution (20-30 m) sensor may be filled leading to much needed regular monitoring of peatland fires.

\section{Materials and Methods}

\subsection{Study Site}

Central Kalimantan is located at coordinates of $0^{\circ} 45^{\prime} \mathrm{N}-3^{\circ} 30^{\prime} \mathrm{S}$ and $110^{\circ} 45^{\prime} \mathrm{E}-115^{\circ} 51^{\prime} \mathrm{E}$ [43]. It was selected as the study area due to the concentration of peatland of about 2.6 million ha, or $52 \%$ of the total peatland in Kalimantan. According to the Indonesian Bureau of Statistics (BPS) [44], palm oil plantations occupy about 1.1 million ha in Central Kalimantan and most plantations exist in the peatland area. The algorithm development site inside the Central Kalimantan province was chosen based on analysis of optimised 'Hot Spot' of MODIS active fire product using the Getis-Ord method, which identifies a statistically significant spatial cluster of high values or 'Hot Spots' and low values or 'Cold Spots' [45,46]. The Getis-Ord analysis of daily MODIS active fires from 2007-2017, as presented in Figure 1A, shows a high density of active fires or areas which can be regarded as fire prone in red 
polygons located in southern part of Central Kalimantan Province. The high density of fire-prone areas was overlaid with the peatland zones in green polylines from The Ministry of Agriculture (MoA). This shows that the fires in Central Kalimantan predominantly occur in peatland. The Landsat- 8 coverage of path/row 118/062 (magenta rectangle) in Figure 1A matched the location of this fire-prone area in the peatland of Central Kalimantan. Thus, this area was chosen as the algorithm development site (Figure 1A).

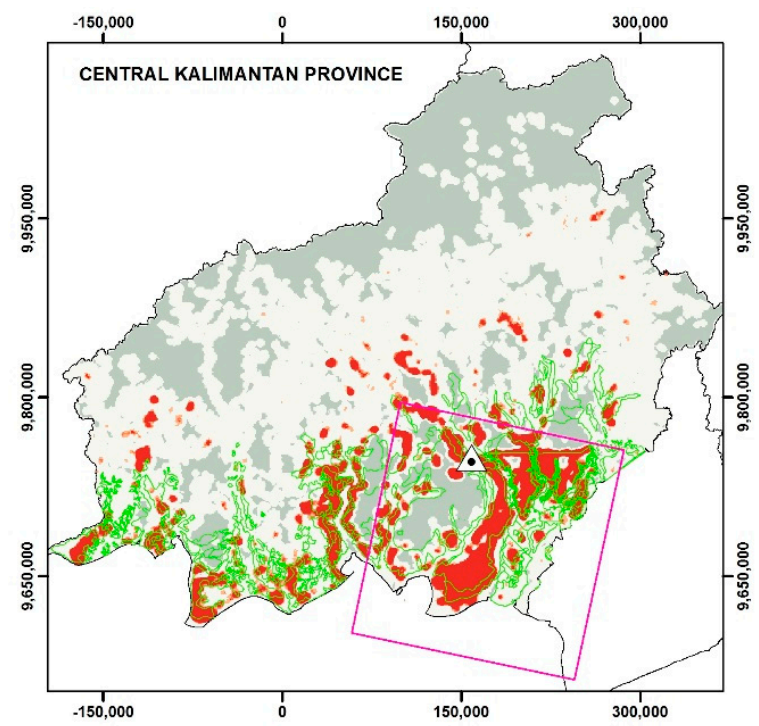

Hot Spot Analysis of MODIS Active Fire (Getis-Ord Gi*)

(A)



Cluster mapping

Cold Spot: $99 \%$ Confidence

Cold Spot: $95 \%$ Confidence

Cold Spot: $90 \%$ Confidence

Not Significant

Hot Spot: $90 \%$ Confidence

Hot Spot: $95 \%$ Confidence

Hot Spot: $99 \%$ Confidence

- Capital City

$\square$ Province Boundary

Peatland

Landsat coverage


Data source:
- Active fire hotspot from MODIS NASA (2007-2017) - Peatland from MoA

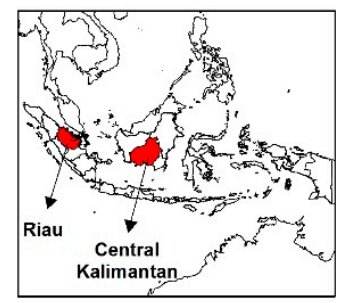

(B)

Figure 1. (A) The algorithm development site analysed from the Getis-Ord optimised hotspot applied to $1 \mathrm{~km}$ grid cell counts of Moderate Resolution Imaging Spectroradiometer (MODIS active fires (2007-2017) overlaid on peatland map in Central Kalimantan and (B) Validation site in Riau Province. The Hot Spots in red tones represent the high density of MODIS active fires with statistically significant confidence levels from $90 \%$ to $99 \%$, while the Cold Spots, in blue tones, represent the low distribution of fire hotspots with statistical significance from $90 \%$ to $99 \%$. The white colour is not statistically significant. The MODIS active fire source from The National Aeronautics and Space Administration-Fire Information for Resource Management System (NASA-FIRMS). Peatland map sources from the Ministry of Agriculture (MoA). The boundary administration is from Geospatial Information Agency (BIG). 
For validation purposes, an area outside of Central Kalimantan was selected in Riau Province. This is located in Sumatera Island with bounding coordinates of $2^{\circ} 25^{\prime} \mathrm{N}-1^{\circ} 05^{\prime} \mathrm{S}$ and $100^{\circ} 00^{\prime} \mathrm{E}-105^{\circ} 05^{\prime} \mathrm{E}$ [47]. Riau Province has a larger peatland and plantation area than Central Kalimantan, with the largest peatland area in Indonesia (3.8 million ha) [48]. The mapping clusters of MODIS active fires in Riau Province are shown in Figure 1B with a dominant high 'Hot Spot' in the northern part of Riau Province (red polygons).

Based on the monthly pattern of rainfall versus the monthly count of MODIS active fires from January 2014-August 2018, the fire season in Central Kalimantan is generally associated with low rainfall levels in the dry season and with high counts of MODIS active fires, which mostly occur from July-October, while in Riau Province the fire-prone time generally occurs in two dry periods of February-March and June-August.

\subsection{Data}

The satellite data used in this study were day-time Landsat-8 acquisitions, which are captured at 9:34 a.m. (local time) for path/row 118/062 in Central Kalimantan Province, Indonesia. Eleven Landsat- 8 scenes with a cloud cover percentage taken from the metadata and haze condition analysed visually from the RGB images, are listed in Table 1. Five 2015 scenes were used for algorithm development in Central Kalimantan, while the other six scenes were used for implementation and validation purposes in Central Kalimantan and Riau province, Indonesia. The Landsat-8 OLI and TIRS data were obtained from the Earth Explorer Data Archive Centre of the United States Geological Survey (USGS) at Level 1T, with standard instrumental radiometric and geometric corrections based on Digital Elevation Model (DEM). The Level 1T product provides a resampling of TIRS thermal bands at $30 \mathrm{~m}$ from $100 \mathrm{~m}$ spatial resolution.

Table 1. List of Landsat- 8 data used for algorithm development and validation. The algorithm development area was in Central Kalimantan using 2015 data, while validation analysis was conducted in Central Kalimantan (2018) and Riau Provinces (2016 and 2018).

\begin{tabular}{cccccc}
\hline Acquisition Date & Path-Row & Study Site & Utilised for & Cloud Cover (over Land) & Haze Condition \\
\hline 3 August 2015 & $118-062$ & Central Kalimantan & development & $1.48 \%$ & no haze \\
19 August 2015 & $118-062$ & Central Kalimantan & development & $1.96 \%$ & thin smoke haze \\
4 September 2015 & $118-062$ & Central Kalimantan & development & $47.2 \%$ & medium smoke haze \\
20 September 2015 & $118-062$ & Central Kalimantan & development & $96.07 \%$ & thick smoke haze \\
22 October 2015 & $118-062$ & Central Kalimantan & development & $99.69 \%$ & thick smoke haze \\
28 September 2018 & $118-062$ & Central Kalimantan & internal validation & $3.96 \%$ & thin smoke haze \\
5 October 2018 & $119-062$ & Central Kalimantan & internal validation & $40.50 \%$ & thin smoke haze \\
20 August 2016 & $127-059$ & Riau & external validation & $29.08 \%$ & thin smoke haze \\
4 April 2018 & $127-059$ & Riau & external validation & $38.67 \%$ & thin smoke haze \\
7 July 2018 & $126-059$ & Riau & external validation & $77.55 \%$ & medium smoke haze \\
7 July 2018 & $126-060$ & Riau & external validation & $43.29 \%$ & medium smoke haze \\
\hline
\end{tabular}

Moreover, pan-sharpened of Satellite Pour 1'Observation de la Terre (SPOT)-6 and SPOT-7 images were used as a reference for fire locations with their high spatial resolution of $1.5 \mathrm{~m}$. The SPOT-6/7 data is available via on demand tasking through the Indonesian National Institute of Aeronautics and Space (LAPAN). During the fire period of 2015, due to the emergency situation of forest/peat fires in Kalimantan, LAPAN was tasked to acquire daily SPOT-6/7 images from LAPAN's ground station. In concordance with the Landsat- 8 data period for developing the peatland combustion detection algorithm, the SPOT-6/7 data were acquired on 15-16 August, 18-22 September and 18 October 2015.

For comparison with an operational active fire data product the NASA Land-SIPS VIIRS $375 \mathrm{~m}$ active fire product (VNP14IMG) were compiled. To validate the peatland fire map results, ground truth was also collected from two sources: historical fire occurrence data from BNPB and direct ground truth in the field. The historical fire data from BNPB in 2015 were collected mainly using a terrestrial camera and GPS locations of the camera. However, in 2018, BNPB had the added capacity to monitor fires using aerial imaging from a drone and helicopters. Direct ground observation in Central Kalimantan was conducted on 28 September-5 October 2018. The data collection taken on direct ground survey 
were the position of peat fires using a GPS Montana 680, surface temperature using an IRtek IR150 dual beam laser infrared thermometer, with a specified temperature range of $-60-1500{ }^{\circ} \mathrm{C}$ and accuracy $\pm 2{ }^{\circ} \mathrm{C}$, terrestrial peat fires pictures taken with a digital camera and aerial images from DJI Phantom Pro 4 drone. In addition weather conditions of air temperature, relative humidity and wind velocity were collected using a handheld anemometer amf-006.

\subsection{Pre-processing of Landsat-8 Data}

The multispectral bands of OLI and the thermal bands of TIRS were radiometrically corrected by converting pixel digital numbers to Top of Atmosphere (TOA) spectral radiance (W m $\mathrm{m}^{-2} \mathrm{sr}^{-1}$ $\mu \mathrm{m}^{-1}$ ) using the radiance rescaling factors in the metadata of Landsat-8. Previous research [39] noted that the SWIR radiance of Landsat-8 at $2.2 \mu \mathrm{m}$ (SWIR-2) over a woody burning area was at or above $24.3 \mathrm{Wm}^{-2} \mathrm{sr}^{-1} \mu \mathrm{m}^{-1}$ and corresponded to $870-970 \mathrm{~K}$ fire temperature. A similar range of SWIR-2 radiance was also found by Sofan et al [49] of about 24-29 Wm ${ }^{-2} \mathrm{sr}^{-1} \mu \mathrm{m}^{-1}$ from the flaming features identified in the 764 RGB images of Landsat-8. To provide a standardised measure, which is directly comparable between images which are acquired in any season, the TOA radiances of SWIR and other multispectral bands of OLI were converted to TOA planetary reflectance. The TIR-1 band (band-10) TOA radiance values were converted to TOA brightness temperatures. These values are predominately influenced by the emitted radiance of the surfaces [50-53]. The atmospheric correction for both OLI and TIRS bands was not applied, as the effect of dynamic smoke haze during fire events was deliberately included for analysis. The spectral properties of Landsat- 8 used in this study can be found in Appendix A Table A1.

\subsection{Separation of Combustion Area and Non-Combustion Area}

Initially, the 2015 historical firefighting location data obtained from BNPB were mainly aimed to guide the location of peatland combustion on a satellite image. However, in the development site (Central Kalimantan) it was discovered that the firefighting locations in 2015 (July-October) predominantly were distributed close to urban areas and there were limited ground validation sites collected for large peatland fires far from urban areas. This geographical bias could be caused by the priority for human safety reasons and/or due to the difficulties in access to peatland fire areas which were largely burning at that time. Thus, the reference of fire locations for development algorithm in 2015 was based on the Red Green Blue (RGB) pan-sharpened images of SPOT-6/7 or the 764 RGB images of Landsat- 8 with smoke as an indicator of fire presence and in some cases its origin.

The tropical peatland combustion algorithm was developed in the area covered by Landsat- 8 path/row 118/062 over Central Kalimantan in the period of August-October 2015. Data for the sample areas of combustion and non-combustion areas were collected on five Landsat- 8 scenes. The types of landcover of the non-combustion area were plantation, forest, burnt area, urban (mixture of buildings, roads, vegetation, etc.), mining, and cloud as the brightest object. Predominantly peat fire locations, based on the historical MODIS active fire product and maps of peatland and landuse, were in or around plantation areas close to forest and burnt areas. Urban, building, mining areas and cloud features are typically bright during day-time with high reflectance, and thus could influence the identification of combustion areas. Thus, these bright objects are the potential sources of commission error for fire detection. We eliminated this source of error by masking out bright non-fire objects from the analysis (including settlement/urban) using the Indonesian national landuse map previously mentioned [29,39,42].

The OLI false colour image composite: bands-764 to RGB was chosen to visually enhance the burning areas from the background objects as SWIR bands (6-7) are sensitive to fire detection [29,39,40,42], while band-4 (visible, red spectrum) highlights smoke. In the 764 RGB image composite of Landsat- 8 , the combustion area exhibits in light yellow tones surrounded with orange and pink tones, with bluish smoke emanating from combustion areas. Flaming shows in bright yellow 
tones indicating a high reflectance value in SWIR-2; smouldering shows in reddish to orange tones, surrounding flaming with smoke from the surface (Figure 2A).

The sample areas of combustion and non-combustion area were delineated separately under clear sky and smoky conditions. There were a total of 238,772 clear sky pixels and 26,237 smoky pixels used as the samples with the type of objects as shown in Table 2. Each pixel is $30 \mathrm{~m} \times 30 \mathrm{~m}$ in size, so in total there was approximately 23,851 ha used for peatland combustion algorithm development. The coefficient of variation within each sample area was less than $30 \%$. The statistics of minimum, maximum, first quartile, median, third quartile and median of each sample area were calculated. Figure $2 \mathrm{~B}$ shows the median values for TOA planetary reflectance of Landsat- 8 from visible to SWIR bands of each sample area in clear sky and smoky conditions. In SWIR-2 the highest reflectance was for flaming pixels (clear sky), then decreasing to smoky flaming, cloud, smouldering, smoky building, smoky smouldering, urban and burnt area, while plantation and forest areas had the least reflectance. The reflectance of all sample areas was higher in smoky conditions than clear sky conditions (Figure 2B), which is caused by high scattering from aerosols in a smoky atmosphere.

Table 2. Sample areas (in pixel) for peatland combustion algorithm development.

\begin{tabular}{ccc}
\hline Object & Clear Sky (Pixel) & Smoky (Pixel) \\
\hline Flaming & 584 & 1,143 \\
Smouldering & 515 & 1,347 \\
Burnt area & 9,068 & 5,107 \\
Forest & 211,501 & 9,160 \\
Plantation & 6,076 & 3,779 \\
Urban & 4,212 & 5,303 \\
Building & 1,640 & 398 \\
Cloud & & \\
Total & 238,772 & \\
\hline
\end{tabular}

The TOA brightness temperature of TIR-1 and the ratio of reflectance SWIR-1 to SWIR-2 of Landsat- 8 for each object of combustion and non-combustion indicate that the flaming combustion had the highest median temperature in TIR-1 (Figure 2C). In smoky conditions, the brightness temperature of flaming and smouldering were lower than in clear sky conditions, as well as the other sample areas. To separate flaming and smouldering pixels from the other background objects, the ratio of SWIR-2 and SWIR-1, based on TOA planetary reflectance values, was calculated and termed the Shortwave Infrared Combustion Index or $\mathrm{SICI}_{\rho}$. The median values of $\mathrm{SICI}_{\rho}$ were plotted in Figure $2 \mathrm{C}$ showing the flaming and smouldering threshold for both clear sky and smoky conditions in the scale of $\mathrm{SICI}_{\rho}$ to be above 1.0. This value was adopted to separate combustion and non-combustion objects. Even though, the $\mathrm{SICI}_{\rho}$ threshold was close to that of burnt area objects, this threshold was used to deliberately over classify potential combustion areas. This over estimation was subsequently eliminated using TOA reflectance of SWIR-2 and TOA brightness temperature of TIR-1. 

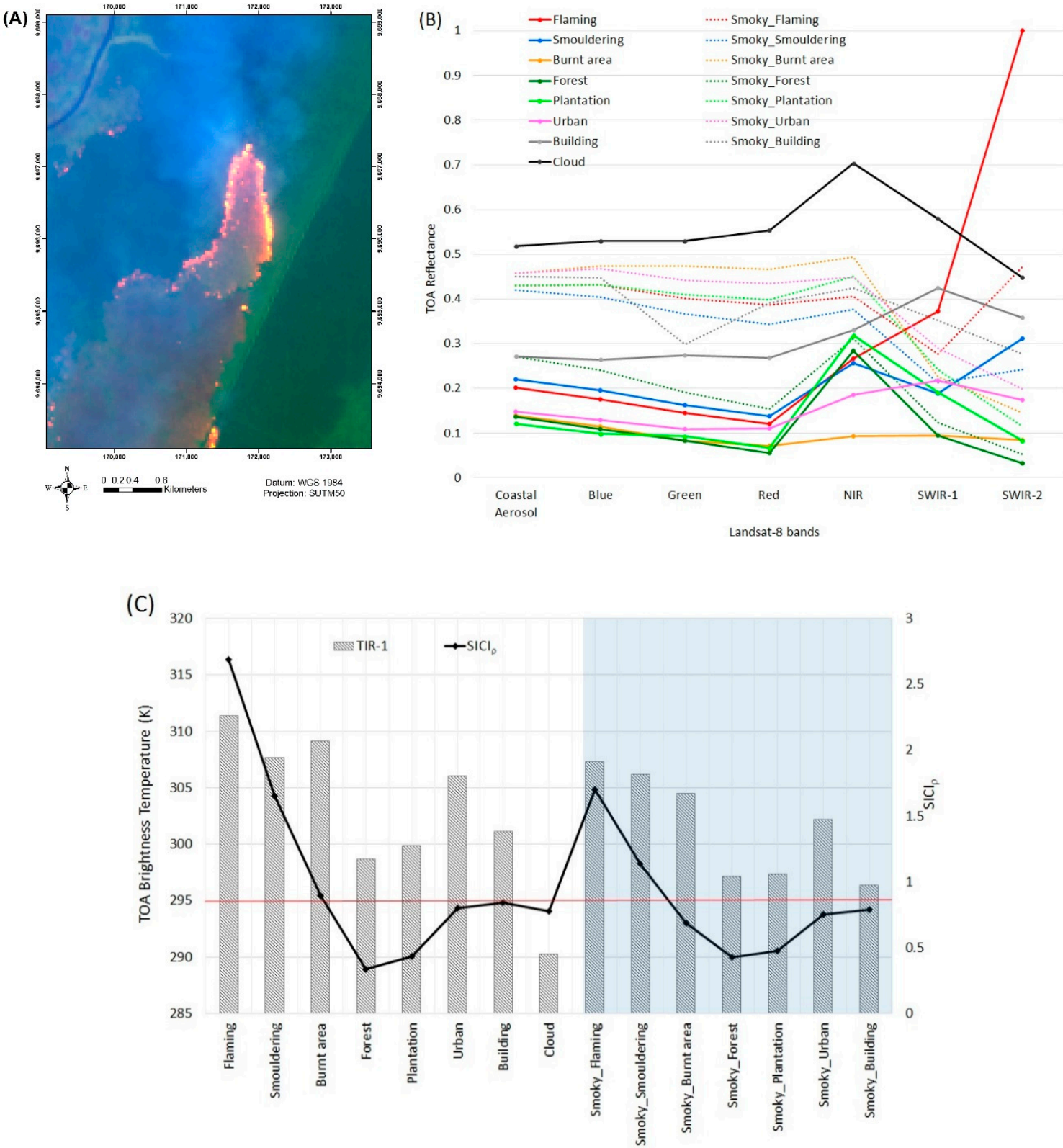

Figure 2. (A) An example of a combustion area on the 764 Red Green Blue (RGB) images of Landsat-8 on September 20, 2015 with combustion area surrounding non-combustion area (forest, plantation, burnt area), (B) The Top of Atmosphere (TOA) planetary reflectance values of Landsat- 8 bands. The solid line pattern refers to objects in clear sky condition, while the dotted line pattern relates to smoky objects, (C) The median values of TOA brightness temperatures of Thermal Infrared band-10 (TIR-1) plotted in the clustered column, while the median values of the ratio of Shortwave Infrared band-7 (SWIR-2) and SWIR-1 reflectance, Shortwave Infrared Combustion Index $\left(\mathrm{SICI}_{\rho}\right)$, are shown in a black line with markers. Smoky conditions are shown in the light blue shading area to the right of clear sky conditions on the left. The red line is $\mathrm{SICI}_{\rho}$ threshold used to separate flaming and smouldering from other background objects.

\subsection{Smoke Haze Distribution}

One of the designations for the coastal aerosol band (band-1) in the OLI sensor of Landsat- 8 is to sense aerosol particles such as smoke and haze in the atmosphere (USGS, 2018). However, the detection of aerosol properties of smoke using band-1 of Landsat- 8 still lacks research. Heavy smoke may obscure the detection of forest/land fire using optical satellite data during fire season, but it also has a cooling 
effect on the atmospheric temperature [54]. Here the coastal aerosol band-1 of Landsat-8 is used to generally classify clear sky and smoky conditions, using the median value in band-1 reflectance (shown in Figure 2B), corresponding to a TOA reflectance threshold of 0.27.

\subsection{Tropical Peatland Combustion Algorithm}

The Tropical Peatland Combustion Algorithm (ToPeCAl) algorithm developed here consists of three criteria, i.e., (i) a threshold for $\mathrm{SICI}_{\rho}$ of 1 to separate the potential combustion areas (including bright objects) from non-combustion areas, (ii) a threshold of reflectance in band- 1 of 0.27 for smoke haze distribution mapping, and (iii) identification and separation of flaming and smouldering peat combustion. The identification of flaming and smouldering peat was based on the SWIR-2 reflectance and TIR-1 brightness temperature, which were divided into two general atmosphere conditions, i.e., clear sky condition and smoky condition.

As mentioned in Section 2.4 and in Figure 2C, the flaming and smouldering combustion states occurred when values of $\mathrm{SICI}_{\rho}$ were greater than 1 . However, in the case of pixels in between radiance maximum to saturated levels of radiance in SWIR-1 and SWIR-2, the SICI $\rho$ value will be less than 1 . For example, in Figure 3, the combustion areas with high reflective pixels were extracted; there were three of 10 pixels which had $\operatorname{SICI}_{\rho}$ values less than 1 (pixel\#2, pixel\#3, and pixel\#7). Here, both SWIR-1 and SWIR-2 of those three pixels had TOA reflectance greater than 1 and $\mathrm{SICI}_{\rho} \leq 1$-these were classified as flaming pixels. The condition of pixels in $\mathrm{SICI}_{\rho} \leq 1$ should be in line with the conditions in SWIR-2 reflectance and the brightness temperature of TIR-1. For flaming pixels in clear sky conditions, the first quartile value of SWIR-2 reflectance (0.68) and TIR-1 brightness temperature (307 K) were adopted as thresholds, while in smoky conditions, 0.47 for SWIR-2 reflectance and $303 \mathrm{~K}$ for TIR-1 brightness temperature were adopted. According to Morfit et al [55], the maximum radiance for saturated levels of SWIR-1 and SWIR-2 are 71.3-96 Wm $\mathrm{Wm}^{-2} \mathrm{sr}^{-1} \mu \mathrm{m}^{-1}$ and $24.3-29 \mathrm{Wm}^{-2} \mathrm{sr}^{-1} \mu \mathrm{m}^{-1}$, respectively. The saturation in SWIR-1 and SWIR-2 can be caused by fires [39] and lava [56].



(A)

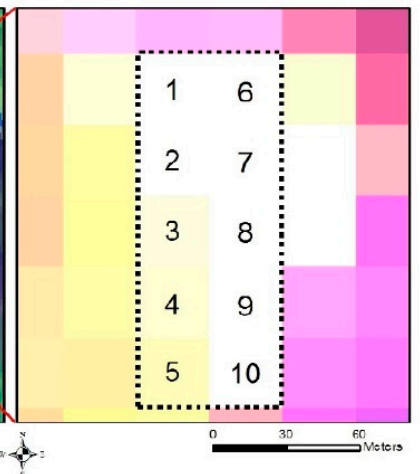

(B)



(C)

Figure 3. (A) Sample of combustion area in the 764 RGB image of Landsat- 8 on 19 August 2015 which had high reflectance of SWIR-1 and SWIR-2, (B) the enlargement of combustion areas showing 10 sample pixels, (C) the extracted SWIR-1 and SWIR-2 reflectances with $\mathrm{SICI}_{\rho}$ values; pixel\#2, \#3, and \#7 had $\operatorname{SICI}_{\rho} \leq 1$.

For smouldering pixels, the $\mathrm{SICI}_{\rho}$ is greater than 1, with the condition that SWIR-2 reflectance ranges from minimum to median value 0.09-0.31 (clear sky conditions) and 0.11-0.32 (smoky conditions). In addition, the minimum value of brightness temperature of TIR- 1 was set at $297 \mathrm{~K}$ in clear sky and smoky conditions. Moreover, when pixels consist of a mix of flaming and smouldering, which may occur around combustion areas, an adjustment of thresholds for SWIR-2 reflectance and TIR-1 brightness temperature values between flaming and smouldering were used. Based on the statistical results of $\mathrm{SICI}_{\rho}$, SWIR-2 reflectance and TIR-1 brightness temperature, the ToPeCAl can be formulated as in Table 3: 
Table 3. The ToPeCAl for smouldering (S), mixture of flaming and smouldering (FS), and flaming (F) detection over clear sky conditions and smoky conditions. The criterion of $\operatorname{SICI}_{\rho}$ must be satisfied together with the threshold values for SWIR-2 reflectance and TIR-1 brightness temperature (BT) of Landsat-8 data.

\begin{tabular}{|c|c|c|c|c|c|c|c|}
\hline Combustion Types & $\begin{array}{c}\text { Criterion } 1 \\
\text { SICI }_{\rho}\end{array}$ & AND & $\begin{array}{c}\text { Criterion } 2 \\
\rho_{\text {band-1 }} \\
\end{array}$ & AND & $\begin{array}{c}\text { Criterion } 3 \\
\rho_{\text {SWIR-2 }} \\
\end{array}$ & AND & $\begin{array}{l}\text { Criterion } 4 \\
\text { BT }_{\text {TIR-1 }}(\mathrm{K}) \\
\end{array}$ \\
\hline $\mathrm{S}$ & $>1$ & & & & $\geq 0.09$ and $\leq 0.31$ & & $\geq 297$ \\
\hline FS & $>1$ & & 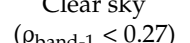 & & $>0.31$ & & $>300$ \\
\hline $\mathrm{F}$ & $>1$ & & & & $\geq 0.68$ & & $\geq 307$ \\
\hline $\mathrm{F}$ (for close to saturated pixel) & $\leq 1$ & & $\begin{array}{c}\text { Clear sky } \\
\left(\rho_{\text {band- }-1<0.27)}\right.\end{array}$ & & $\geq 0.68$ & & $\geq 307$ \\
\hline S & $>1$ & & & & $\geq 0.11$ and $\leq 0.32$ & & $\geq 297$ \\
\hline FS & $>1$ & & $\begin{array}{c}\text { Smoky } \\
\left(\rho_{\text {band- } 1} \geq 0.27\right)\end{array}$ & & $\geq 0.32$ and $\leq 0.47$ & & $>297$ \\
\hline $\mathrm{F}$ & $>1$ & & & & $\geq 0.47$ & & $\geq 303$ \\
\hline F (for close to saturated pixel) & $\leq 1$ & & $\begin{array}{c}\text { Smoky } \\
\left(\rho_{\text {band- }-1} \geq 0.27\right)\end{array}$ & & $\geq 0.47$ & & $\geq 303$ \\
\hline
\end{tabular}

In summary, the processing steps of peatland combustion mapping using Landsat- 8 data are outlined in Figure 4.

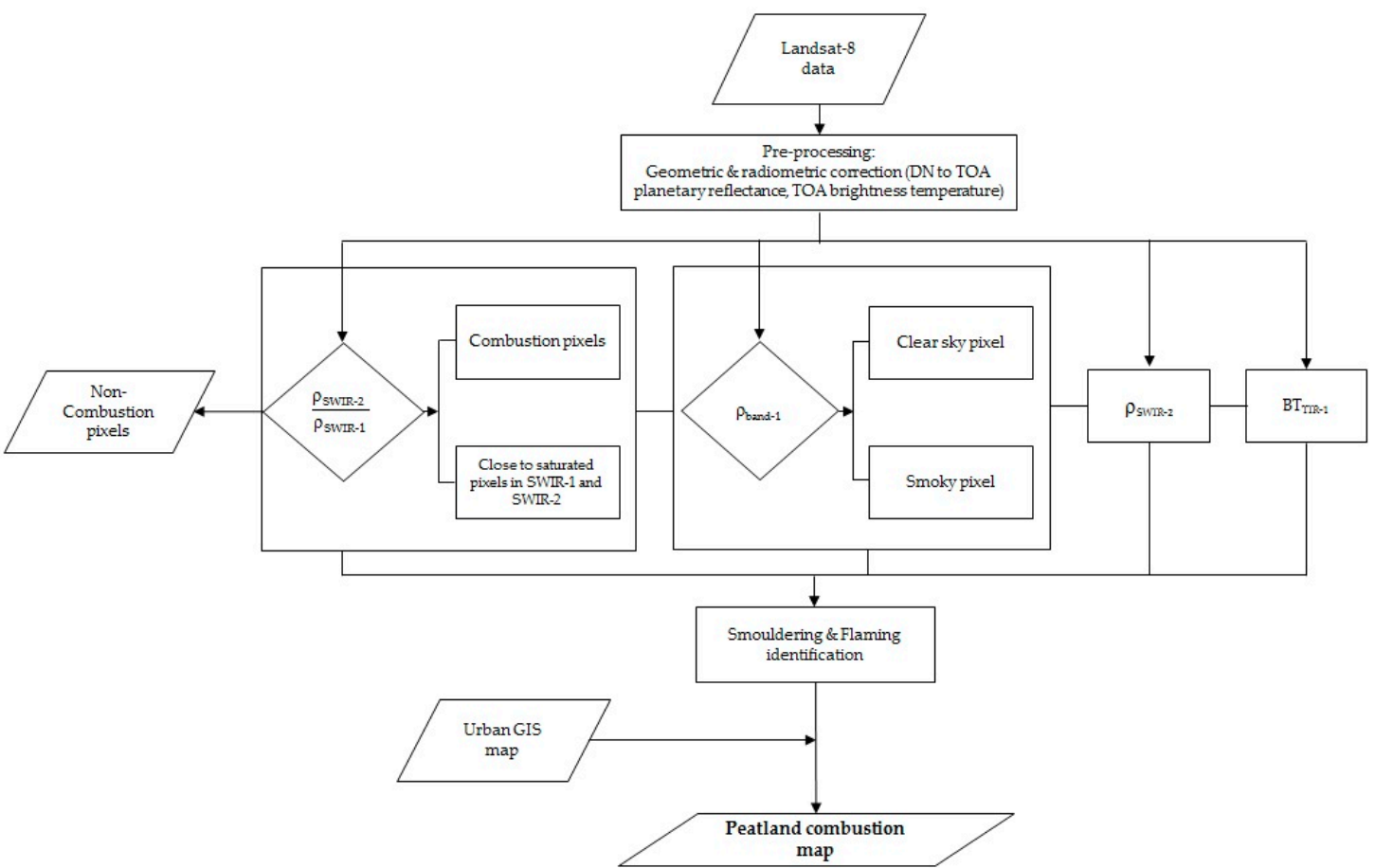

Figure 4. Flowchart of Landsat-8 image processing for mapping tropical peatland combustion.

\subsection{Comparison with the Previous Landsat-8 Active Fire of Global Operational Land Imager}

The Global Operational Land Imager (GOLI) active fire algorithm [42] uses Landsat 8 day time TOA planetary reflectance in SWIR-1, SWIR-2, and visible red band, with bright object subtraction using either SWIR-2 reflectance or Normalised Difference Vegetation Index (NDVI). In contrast, ToPeCAl uses TOA planetary reflectance of SWIR-2 and TOA brightness temperature of TIR-1, with elimination of non-combustion areas using a SICI $\rho$ threshold and masking for building rooftops using a Landuse GIS dataset. According to Kumar and Roy [42], GOLI had omission errors in the tropical peatland fire environment in Indonesia (49 of 77 fires) and is compared here to the ToPeCAl results on 28 September 2018, in Central Kalimantan, Indonesia. 


\subsection{Validation with Ground Truth}

Not all of the peatland combustion mapping results were validated directly on the ground due to accessibility difficulties from the road and the large size of some fires. Most of the ground truth data locations were collected about $0-2 \mathrm{~km}$ away from the fire area. Thus point to point checking was used to validate the ToPeCAl results with the ground truth data with Yes and No scores. The Yes and No scores of ground truth data versus $\mathrm{ToPeCAl}$ results mapping were summarised in a contingency table as shown in generic form in Table 4 . In the contingency table a count of each peatland combustion category (smouldering (S), flaming and smouldering (FS) and flaming (F)) and also the non-combustion area (Non) from the field was compared to the mapping results entries from ToPeCAl.

Table 4. The design of the Contingency Table comparing ToPeCAl mapping versus ground truth. Four categories ((S, FS and F, and non-combustion area (Non)) were assessed for both ground truth data and ToPeCAl results.

\begin{tabular}{ccccccc}
\hline & & \multicolumn{5}{c}{ ToPeCAl Results Mapping } \\
& Categories & S & FS & F & Non & Total \\
\hline \multirow{4}{*}{ Ground truth } & $\mathrm{S}$ & $\mathrm{a}_{1}$ & $\mathrm{a}_{2}$ & $\mathrm{a}_{3}$ & $\mathrm{a}_{4}$ & $\mathrm{G} \Sigma_{\mathrm{S}}$ \\
& $\mathrm{FS}$ & $\mathrm{b}_{1}$ & $\mathrm{~b}_{2}$ & $\mathrm{~b}_{3}$ & $\mathrm{~b}_{4}$ & $\mathrm{G} \Sigma_{\mathrm{FS}}$ \\
& $\mathrm{F}$ & $\mathrm{c}_{1}$ & $\mathrm{c}_{2}$ & $\mathrm{c}_{3}$ & $\mathrm{c}_{4}$ & $\mathrm{G} \Sigma_{\mathrm{F}}$ \\
& $\mathrm{Non}$ & $\mathrm{d}_{1}$ & $\mathrm{~d}_{2}$ & $\mathrm{~d}_{3}$ & $\mathrm{~d}_{4}$ & $\mathrm{G} \Sigma_{\text {Non }}$ \\
& Total & $\mathrm{T} \Sigma_{\mathrm{S}}$ & $\mathrm{T} \Sigma_{\mathrm{FS}}$ & $\mathrm{T} \Sigma_{\mathrm{F}}$ & $\mathrm{T} \Sigma_{\text {Non }}$ & $\Sigma$ \\
\hline
\end{tabular}

The scores computed from the counts in the contingency table (Table 4) are Percent Correct (PC), False Alarm Ratio (FAR), Probability of Detection (POD), and bias (BIAS). PC is the total percent of correct mapping (the diagonal elements), including hits $\left(\mathrm{a}_{1}, \mathrm{~b}_{2}, \mathrm{c}_{3}\right)$ and correct rejections $\left(\mathrm{d}_{4}\right)$ divided by the total number of data $(\Sigma)$. FAR is the proportion of positive mapping results which did not occur in ground truth. POD refers to the portion of the mapping category that was correctly classified as the same category in ground truth. BIAS measures the mapping ability which demonstrates either over (BIAS > 1) or under estimation (BIAS $<1$ ). It is calculated by dividing the sum of the counts of mapping results $\left(\mathrm{T} \Sigma_{\mathrm{S}}, \mathrm{T} \Sigma_{\mathrm{FS}}, \mathrm{T} \Sigma_{\mathrm{F}}, \mathrm{T} \Sigma_{\mathrm{Non}}\right)$ by the sum of the counts of ground truth in each category $\left(\mathrm{G} \Sigma_{\mathrm{S}}, \mathrm{G} \Sigma_{\mathrm{FS}}, \mathrm{G} \Sigma_{\mathrm{F}}, \mathrm{G} \Sigma_{\mathrm{Non}}\right)$. Referring to the generic variables in Table 4, the mapping scores can be formulated as follows [57,58]:

$$
\begin{gathered}
\mathrm{PC}(\%)=\frac{\mathrm{a}_{1}+\mathrm{b}_{2}+\mathrm{c}_{3}+\mathrm{d}_{4}}{\Sigma} \times 100 \\
\mathrm{FAR}(\%)=\frac{d_{1}}{\mathrm{~T} \Sigma_{\mathrm{S}}}, \frac{d_{2}}{\mathrm{~T} \Sigma_{\mathrm{FS}}}, \frac{d_{3}}{\mathrm{~T} \Sigma_{\mathrm{F}}}, \frac{d_{4}}{\mathrm{~T} \Sigma_{N o n}} \times 100 \\
\operatorname{POD}(\%)=\frac{\mathrm{a}_{1}}{\mathrm{G} \Sigma_{\mathrm{S}}}, \frac{\mathrm{a}_{1}}{\mathrm{G} \Sigma_{\mathrm{S}}}, \frac{\mathrm{b}_{2}}{\mathrm{G} \Sigma_{\mathrm{FS}}}, \frac{\mathrm{c}_{3}}{\mathrm{G} \Sigma_{\mathrm{F}}}, \frac{\mathrm{d}_{4}}{\mathrm{G} \Sigma_{\mathrm{Non}}} \times 100 \\
\operatorname{BIAS}(\%)=\frac{\mathrm{T} \Sigma_{\mathrm{S}}}{\mathrm{G} \Sigma_{\mathrm{S}}}, \frac{\mathrm{T} \Sigma_{\mathrm{FS}}}{\mathrm{G} \Sigma_{\mathrm{FS}}}, \frac{\mathrm{T} \Sigma_{\mathrm{F}}}{\mathrm{G} \Sigma_{\mathrm{F}}}, \frac{\mathrm{T} \Sigma_{\mathrm{Non}}}{\mathrm{G} \Sigma_{\text {Non }}}
\end{gathered}
$$

For perfect mapping, the value of Percent Correct $(\mathrm{PC})=100 \%$, False Alarm Ratio (FAR) $=0 \%$, Probability of Detection $(\mathrm{POD})=100 \%$, and bias $(\mathrm{BIAS})=1$

\subsection{Comparison with the $375 \mathrm{~m}$ Visible Infrared Imaging Radiometer Suite Active Fire Product}

The VNP14IMG fire pixels consist of three classes of fire pixel detection, i.e., low confidence, nominal confidence, and high confidence. The low confidence fire pixels have an effect of water sun glint during day-time and a weak temperature anomaly less than $15 \mathrm{~K}$, while the nominal confidence level of fire pixel has no contamination due to sun glint and a strong temperature anomaly greater than $15 \mathrm{~K}$. The high confidence level of fire pixels refers to saturated pixels [59]. 
Here a preliminary analysis was conducted to explore the possibility of merging VNP14IMG with ToPeCAl results from Landsat-8 by firstly, comparing VNP14IMG to the same ground truth used to validate the ToPeCAl results, and secondly comparing VNP14IMG directly to the Landsat -8 ToPeCAl results.

In comparison with ground truth data, all the fire level confidences of VNP14IMG were classified into a single fire class as was the ground truth data. The same method of point to point checking validation described in the Section 2.8 was used in the validation of VIIRS active fire versus ground truth data, with one class of fire (Table 5A). Meanwhile, in comparison with the ToPeCAl result from Landsat-8, there were two techniques for comparison used, i.e., (i) single fire class comparison for both ToPeCAl and VNP14IMG (Table 5B), and (ii) multiple fire class comparison with three combustion classes of ToPeCAl versus one fire class of VNP14IMG (Table 5C). For the single fire class comparison, the ToPeCAl combustion classes (S, FS, and F) were converted to a single fire class to compare with VNP14IMG data. In addition no comparisons were made with low, nominal, and high confidence levels.

Table 5. (A) The design of the Contingency Table for the VNP14IMG product versus ground truth data, (B) the VNP14IMG product versus Tropical Peatland Combustion Algorithm (ToPeCAl) results from Landsat- 8 based on two categories (Yes-Fire, No-Fire), and (C) the VNP14IMG product versus ToPeCAl applied to Landsat-8 based on four categories (F, S, FS, and Non).

\begin{tabular}{|c|c|c|c|c|}
\hline & & (A) & & \\
\hline & & \multicolumn{3}{|c|}{ VNP14IMG } \\
\hline \multirow{4}{*}{ Ground truth } & Categories & Yes-Fire & No-Fire & Total \\
\hline & Yes-Fire & $\mathrm{a}_{1}$ & $a_{2}$ & $\mathrm{G} \Sigma_{\text {Yes-Fire }}$ \\
\hline & Yes-Fire & $\mathrm{b}_{1}$ & $\mathrm{~b}_{2}$ & $\mathrm{G} \Sigma_{\text {No-Fire }}$ \\
\hline & Total & $\mathrm{V} \Sigma_{\text {Yes-Fire }}$ & $\mathrm{V} \Sigma_{\text {No-Fire }}$ & $\Sigma$ \\
\hline \multicolumn{5}{|c|}{ (B) } \\
\hline & & \multicolumn{3}{|c|}{ VNP14IMG } \\
\hline \multirow{4}{*}{$\begin{array}{c}\text { ToPeCAl } \\
\text { Total }\end{array}$} & Categories & Yes-Fire & No-Fire & \multirow{4}{*}{$\begin{array}{c}\text { Total } \\
\mathrm{T} \Sigma_{\text {Yes-Fire }} \\
\mathrm{T} \Sigma_{\text {No-Fire }} \\
\Sigma \\
\end{array}$} \\
\hline & Yes-Fire & $\mathrm{a}_{1}$ & $\mathrm{a}_{2}$ & \\
\hline & No-Fire & $b_{1}$ & $b_{2}$ & \\
\hline & $\mathrm{V} \Sigma_{\text {Yes-Fire }}$ & $\mathrm{V} \Sigma_{\text {No-Fire }}$ & $\Sigma$ & \\
\hline \multicolumn{5}{|c|}{ (C) } \\
\hline & & \multicolumn{2}{|c|}{ VNP14IMG } & Total \\
\hline \multirow{5}{*}{ ToPeCAl } & Categories & Yes-Fire & No-Fire & \\
\hline & $\mathrm{S}$ & $a_{1}$ & $a_{2}$ & $\mathrm{~T} \Sigma_{\mathrm{S}}$ \\
\hline & FS & $b_{1}$ & $b_{2}$ & $\mathrm{~T} \Sigma_{\mathrm{FS}}$ \\
\hline & $\mathrm{F}$ & $c_{1}$ & $\mathrm{c}_{2}$ & $\mathrm{~T} \Sigma_{\mathrm{F}}$ \\
\hline & Non & $\mathrm{d}_{1}$ & $\mathrm{~d}_{2}$ & $\mathrm{~T} \Sigma_{\text {Non }}$ \\
\hline Total & & $\mathrm{V} \Sigma_{\text {Yes-Fire }}$ & $\mathrm{V} \Sigma_{\text {No-Fire }}$ & $\Sigma$ \\
\hline
\end{tabular}

Before conducting the comparisons, the raster cells of ToPeCAl were converted to polygons, while the VNP14IMG data were converted from point to polygon format using spatial buffering of $187.5 \mathrm{~m}$ (half a VIIRS pixel), $375 \mathrm{~m}$ (one VIIRS pixel), $500 \mathrm{~m}, 750 \mathrm{~m}, 1000 \mathrm{~m}, 1250 \mathrm{~m}$, and $1500 \mathrm{~m}$ (Figure 5). Spatial buffering at increasing distances was applied to VNP14IMG points so that the spatial relationship and corresponding accuracy assessment metrics could be analysed. The data used for both VNP141IMG and Landsat-8 was from 28 September 2018. The Landsat-8 image was acquired at 2:34 UTC, while VNP141IMG data was acquired at 5:30 UTC and 18:12 UTC; thus there was approximately 3 hours and 15 hours of time difference, respectively. Firstly, the comparison of ToPeCAl was conducted using the 3 hours time lag of VNP14IMG data, and secondly the combined VNP14IMG data (5:30 and 18:12 UTC) was used for comparison with ToPeCAl. 


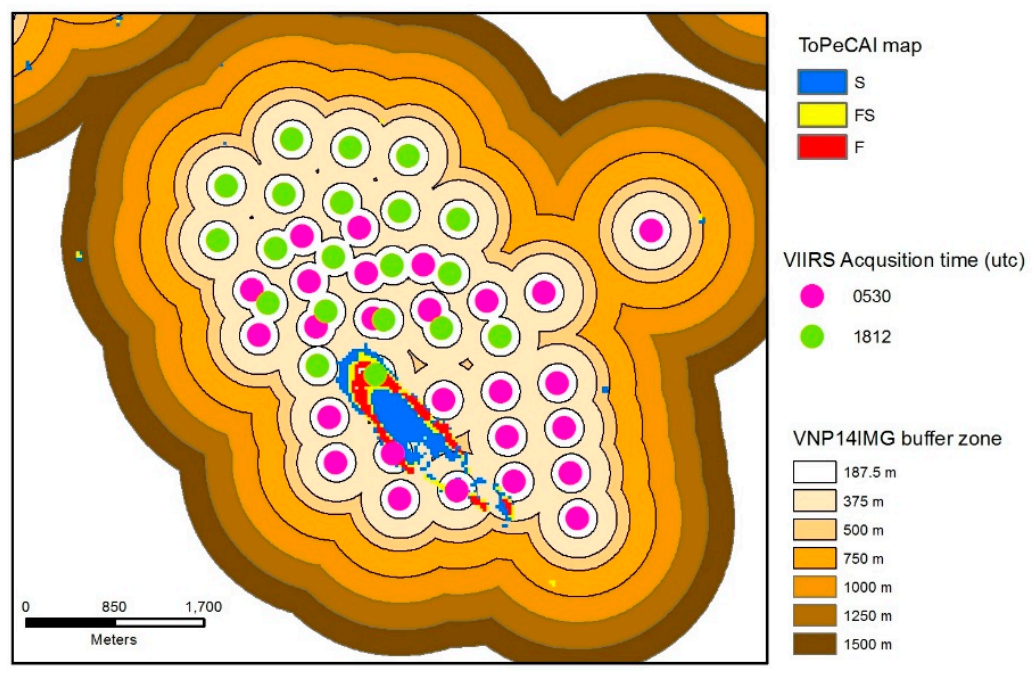

Figure 5. An example of buffering VNP14IMG point data overlaid with ToPeCAl results from Landsat-8. The VNPIMG data and ToPeCAl mapping relates to September 28, 2018. There is a 3 and 15 hour time difference from Landsat- 8 to VNP14IMG acquisition times. The buffer zones are $187.5 \mathrm{~m}, 375 \mathrm{~m}, 500 \mathrm{~m}$, $750 \mathrm{~m}, 1000 \mathrm{~m}, 1250 \mathrm{~m}$, and $1500 \mathrm{~m}$ from both the VNP14IMG points (5:30 UTC and 18:12 UTC).

\section{Results}

\subsection{Implementation of Tropical Peatland Combustion Algorithm}

The algorithm was applied to the five scenes of Landsat- 8 on the 2015 fire period in Central Kalimantan (8 August, 19 August, 4 September, 20 September, and 22 October). There were 1,727 flaming pixels and 1,862 smouldering pixels used to develop the algorithm, but then after the implementation of ToPeCAl, there were a total of 35,892 flaming pixels, 10,411 smouldering pixels and 3379 flaming and smouldering mixed pixels. Examples of implementation of the peatland combustion algorithm on Landsat- 8 images (4 and 20 September 2015) under different atmospheric conditions, i.e., cloudy and thick smoke, are shown in Figure 6. Figure 6A,B shows the burning areas surrounded by clouds were well mapped using visual inspection from the 764 RGB image, where combustion was classified into smouldering (S), mixture of flaming and smouldering (FS), and flaming (F) stages. Under heavy smoke conditions, the combustion area shows in light pink tones on the 764 RGB images of Landsat-8 (Figure 6C), and the mapping performed quite well, even though not all the pink tones in the RGB image were identified by ToPeCAl (Figure 6D). The lack of detection of combustion pixels under the thick smoke could be caused by the simplicity of the smoke classification algorithm. 


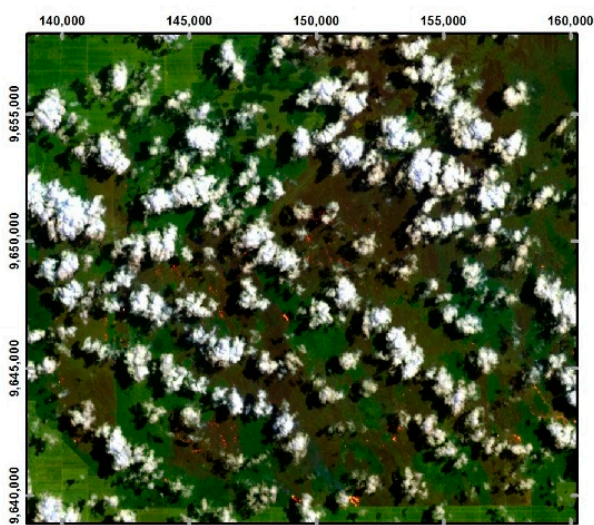

(A)

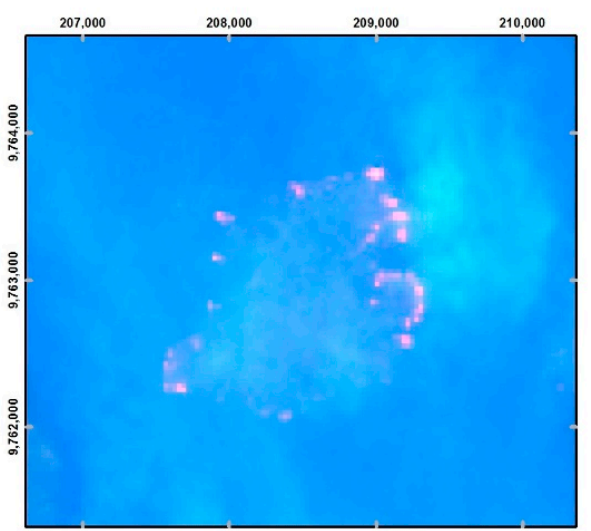

(C)

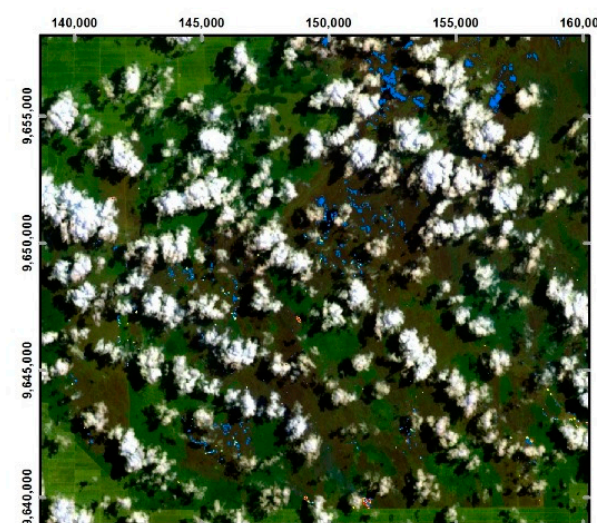

(B)

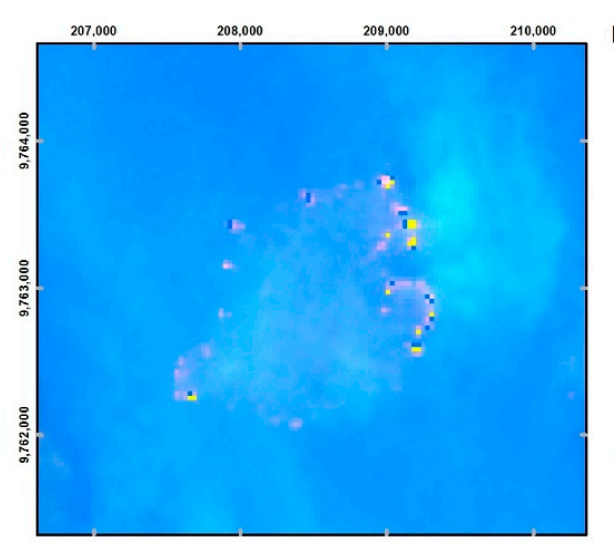

Datum WGS 1984 Projection: S-UTM50

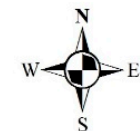

(D)

Figure 6. (A,B) An example of peatland combustion surrounded by cloud cover on a 764 RGB images of Landsat- 8 on 4 September 2015 with the classified peatland combustion, (C,D) Peatland combustion in heavy smoke conditions and the classified peatland combustion on 20 September 2015.

\subsection{Comparison of Tropical Peatland Combustion Algorithm with Global Operational Land Imager Results}

Figure 7 shows the combustion area in the 764 RGB images of Landsat- 8 with bluish smoke emanating from the ground (purple tones) and active fire features in yellow and red tones (Figure 7A). GOLI was implemented over the area and mapped active fire in magenta pixels (Figure 7B), while the ToPeCAl map in Figure 7C shows that most of the purple area (ground and smoke) was identified as smouldering fire. In Figure 7D, an overlay of ToPeCAl and GOLI maps show that ToPeCAl detected a larger peatland combustion area which consisted of smouldering (light blue), mixture of smouldering and flaming (yellow), and flaming (red) pixels. Drone imaging was acquired over a part of the smouldering area two days after the Landsat- 8 acquisition, then overlaid on the ToPeCAl, GOLI, and RGB images (Figure 7E), with an enlargement in Figure 7F that shows a large smouldering area in the field, but no active/flaming fire. 


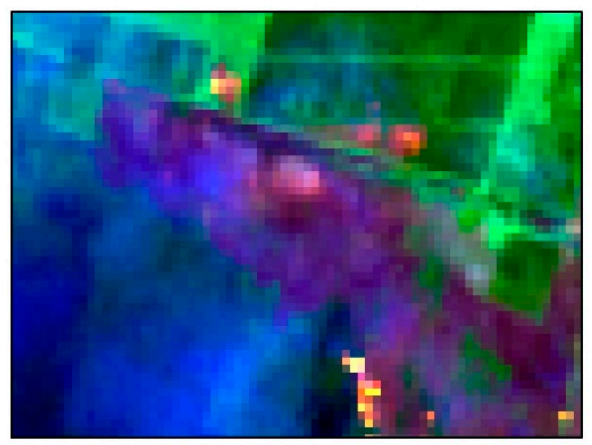

(A)

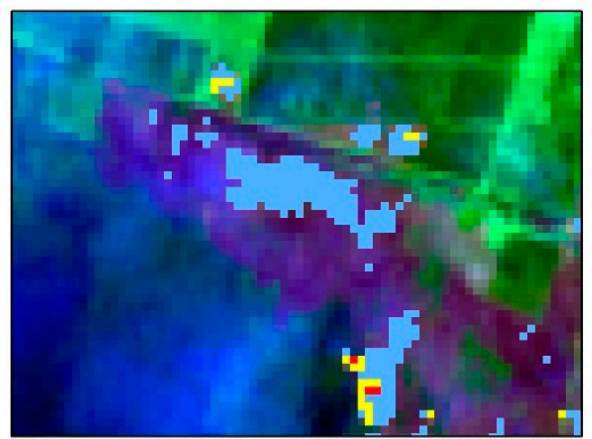

(C)

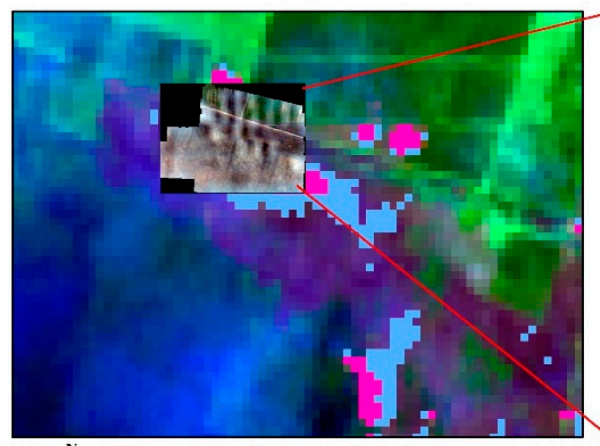

(E)

$0 \quad 210 \quad 420$

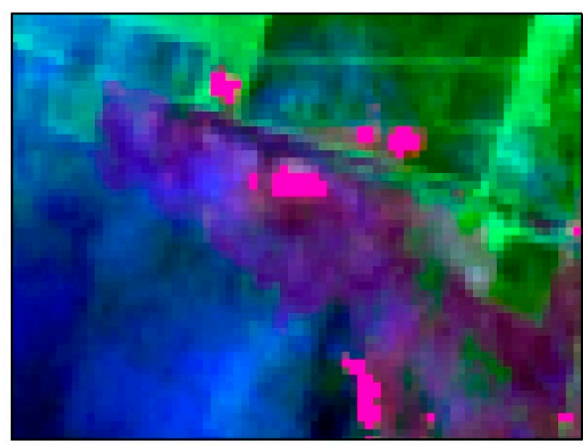

(B)

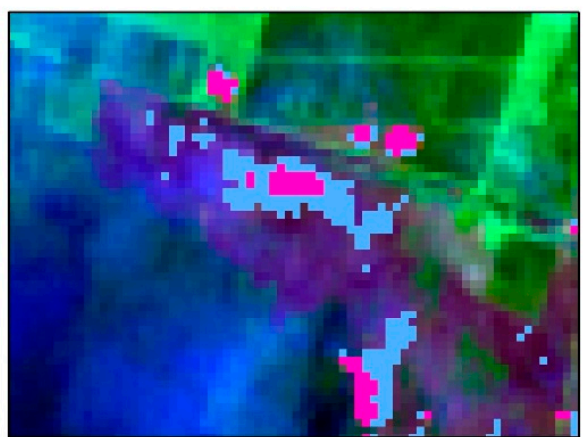

(D)

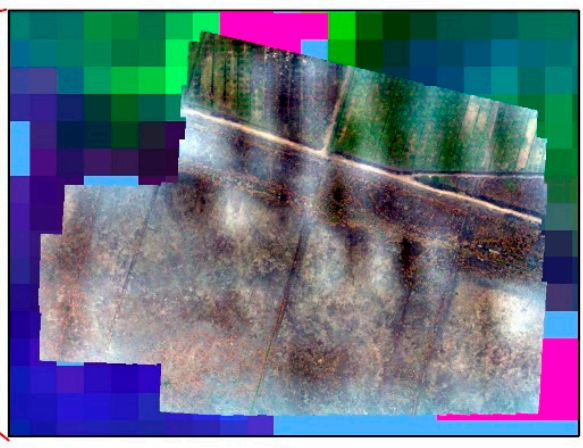

(F)
$60 \quad 120$<smiles>FC1C(=[IH])NC2CNC1C2</smiles>

GOLI

ToPeCA

Active Fire

Figure 7. Comparison of Global Operational Land Imager (GOLI) and ToPeCAl implementation on peatland combustion using Landsat- 828 September 2018, in Central Kalimantan. (A) The 764 RGB images of Landsat- 8 of peatland combustion area, (B) The GOLI active fire (magenta) overlaid on the RGB image, (C) The ToPeCAl mapping result on RGB image is shown in three classes of peatland combustion (S, FS, F), (D). An overlay of GOLI and ToPeCAl showing a larger area of combustion from ToPeCAL, especially for smouldering fire, $(\mathbf{E}, \mathbf{F})$ Drone image and its enlargement showing smouldering peatland but not active/flaming fire.

There is no significant computational time different between GOLI and ToPeCAl methods. Both algorithms are semi-automatic running in remote sensing image processing software. However, additional data, from existing GIS urban/settlement mapping, is needed to minimise the commission errors in ToPeCAl mapping in the finishing stages. 


\subsection{Validation of Tropical Peatland Combustion Algorithm Mapping}

\subsubsection{Internal Validation in Central Kalimantan Province}

There were 101 point locations collected during the ground survey in Central Kalimantan on 27 September-6 October 2018. The points included 82 peat combustion locations and 19 non-combustion areas (burnt area, urban area, reeds, and bright objects). Two scenes of Landsat- 8 data were acquired on 28 September and 5 October 2018. The 28 September 2018 image observed the area of path/row $118 / 062$ which was predominantly in clear sky conditions with thin smoke observed from the ground. According to local BNPB, there were peatland fires in that area since August 2018. Most of the ground locations were collected on path/row 118/062. Meanwhile, the Landsat- 8 image acquired on October 5 (path/row of 119/062) was mostly in cloudy conditions ( $40.5 \%$ cloud cover over land) and fewer ground truth data were collected for this image (Figure 8 ). The average land surface temperature in smouldering peat was measured at $364^{\circ} \mathrm{C}$.

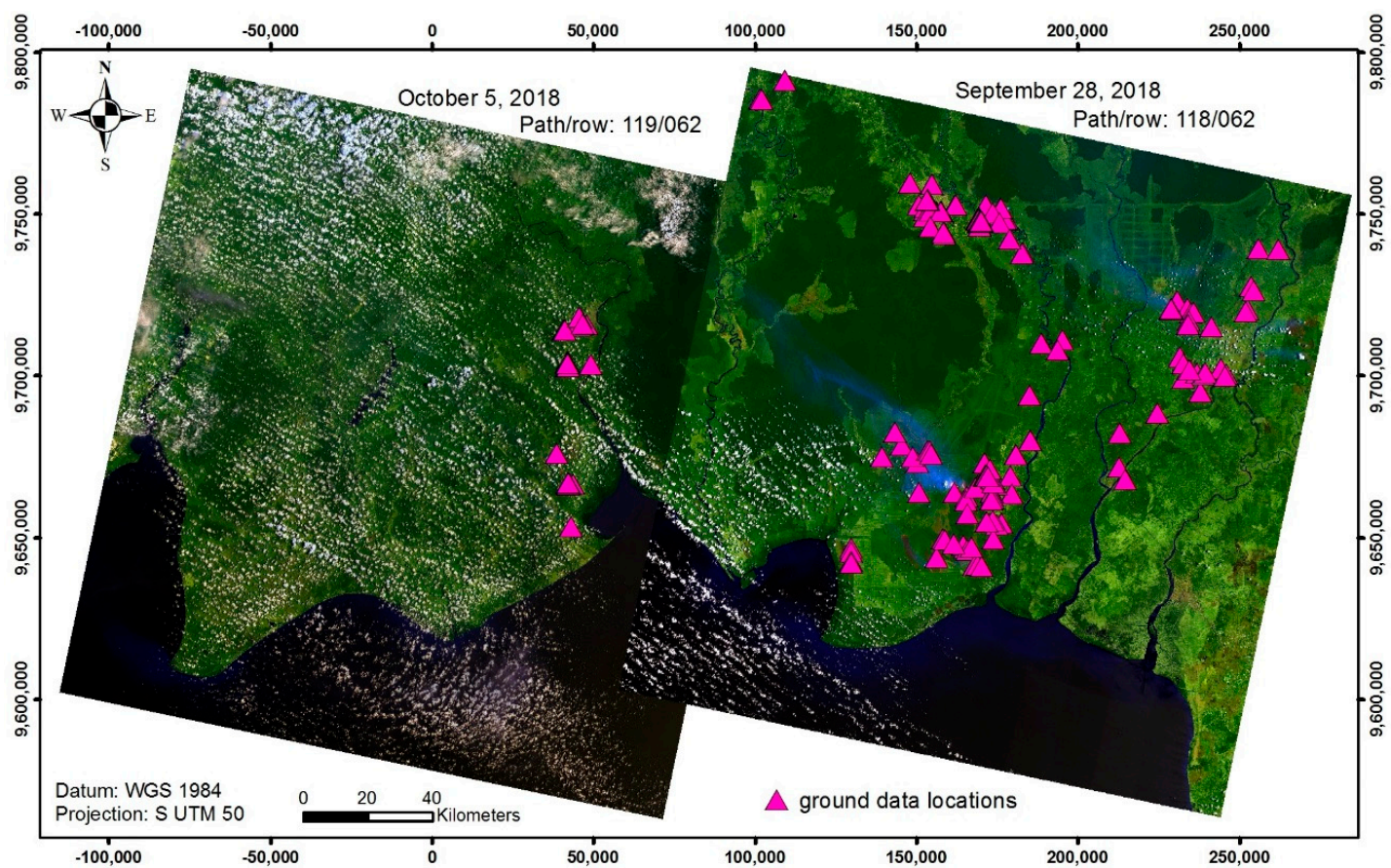

Figure 8. The coverage of ground truth collection in Central Kalimantan (27 September-6 October 2018) overlaid on Landsat-8 images of 28 September 2018 (right) and 5 October 2018 (left).

Figure 9 shows a large peatland fire on 28 September 2018, displaying a large group of flaming pixels in yellow tones in the 764 RGB image of Landsat-8 (Figure 9A). Flaming occurs at the fire-front with smouldering and mixture of flaming and smouldering pixels in orange to reddish tones inside the boundary of fire. The result of peatland combustion mapping corresponds to the 764 RGB images of Landsat- 8 which were classified into three classes; red for flaming, blue for smouldering, and yellow for the mixture of flaming and smouldering pixels (Figure 9B). Ground truth were collected by local BNPB on the same day (28 September 2018) from a helicopter, because of both the large size of the peat fires and their inaccessibility from the land. The location of ground truth base stations is shown by the magenta triangles. The picture taken from the helicopter in Figure $9 \mathrm{C}$ shows the large area of peat fires on the ground. The upper picture was taken from a water bombing helicopter (its shadow is visible in the picture), while the lower picture shows the peatland fires with significant smoke emanating from the ground; this oblique picture was captured from about $2 \mathrm{~km}$ distance from the fire. 
(A)
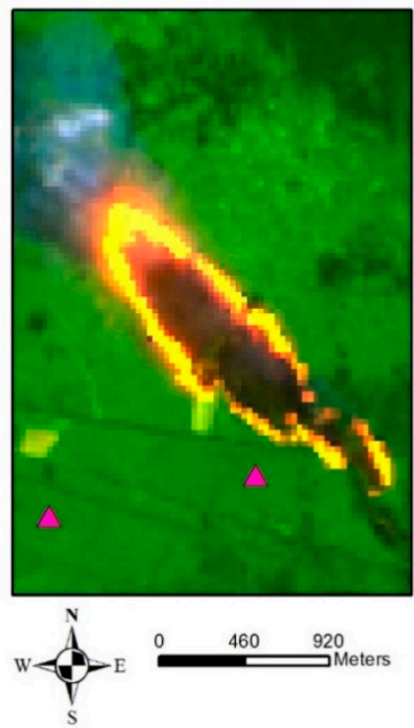

(B)

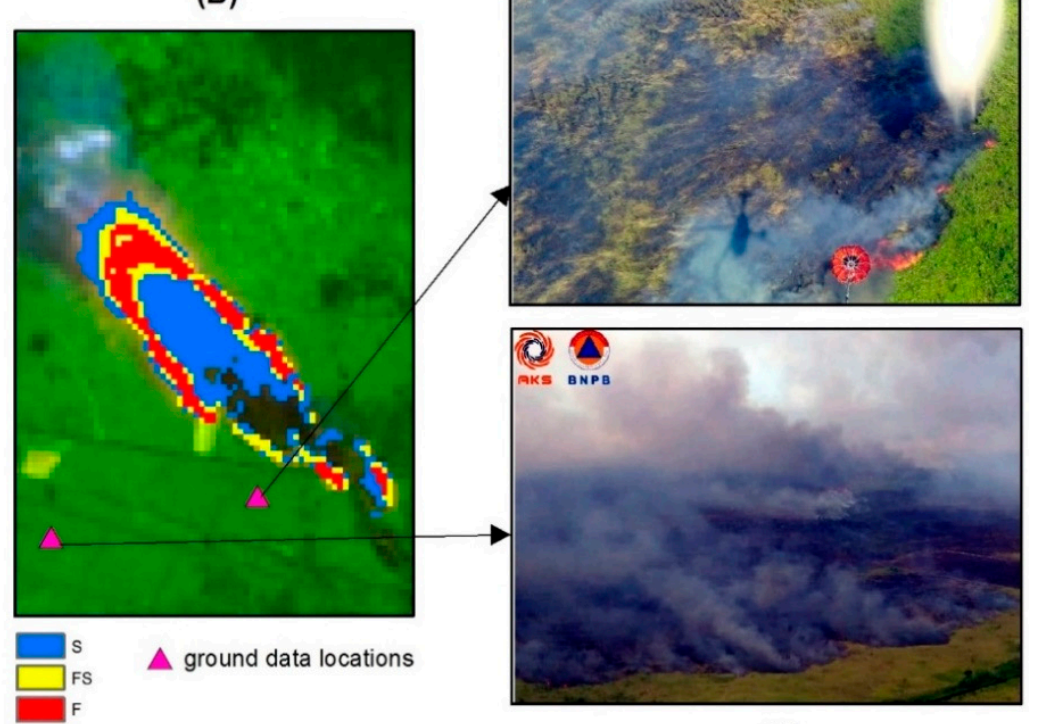

(C)

Figure 9. (A) The 764 RGB image of Landsat-8 on 28 September 2018, (B) The result of ToPeCAl mapping which consists of smouldering (S), mixture of flaming and smouldering (FS), and flaming (F) with ground truth base station locations marked in magenta triangle, $(C)$ The pictures of peatland fires taken from helicopter on 28 September 2018. Field pictures sourced from the local Indonesian Disaster Management Agency (BNPB) of Central Kalimantan Province.

The second example of peatland fires validation was dominated by smouldering fire (Figure 10). The combustion area in the 764 RGB image of Landsat-8 on 28 September 2015 (Figure 10A) presented in dark red tones with flaming features in orange tones and yellow tones. The resulting mapping from ToPeCAl detected the smouldering fire (blue tone) and a small area of flaming (in red) and a mixture of smouldering and flaming (in yellow). A drone was flown on 1 October 2015 over some parts of smouldering area (Figure 10C). The drone image shows a smouldering area with smoke and indicated that the smouldering still existed three days after the Landsat- 8 pass over the area.

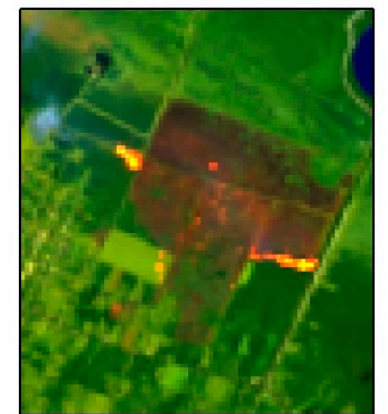

$\underbrace{\mathrm{N}}_{\mathrm{s}}$
(A)

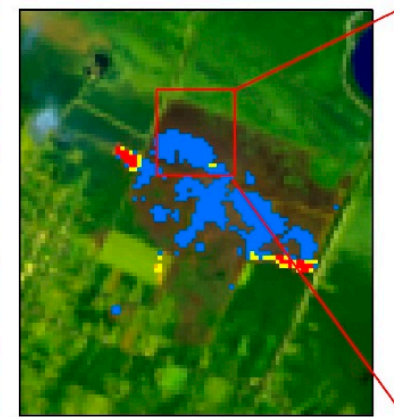

(B)
250500 Meters
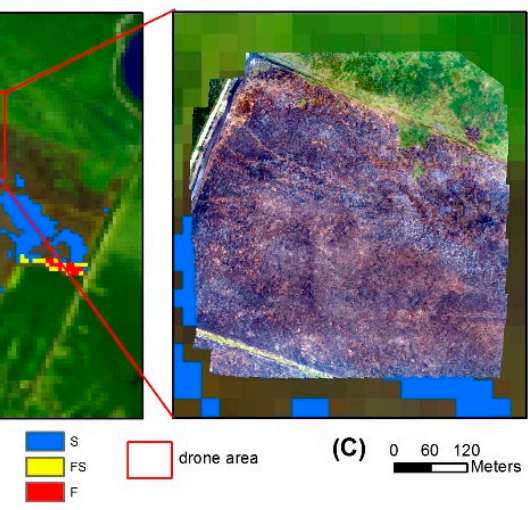

(C) $0 \quad 60 \quad 120$ Meters

Figure 10. (A) The 764 RGB image of Landsat- 8 on 28 September 2018 and (B) the result of peatland combustion mapping with ground truth location marked in red square, $(\mathrm{C})$ The picture of peatland smouldering fire taken from a drone on 1 October 2018. 
The third example of the application of ToPeCAl is shown in Figure 11 where combustion occurred predominantly in a healthy vegetation area. In Figure 11A, the 764 RGB image of Landsat-8 shows a potential combustion area in orange tones around green tones of vegetation. ToPeCAl appeared to perform quite well, indicating there was smouldering and a mixture of flaming and smouldering pixels in that particular area on 5 October 2018 (Figure 11B). One day after that, drone imaging was acquired for the area and it showed (Figure 11C) that the area has been burnt and still had smoke emanating from the ground. Parts of the area included a mixture of green vegetation with smouldering components, as is indicted in Figure 11D. This evidence shows that a mixture of smouldering and green vegetation in a heterogeneous environment might be a possible cause for the lack of detection when ToPeCAl was applied to the Landsat-8 image.

(A)

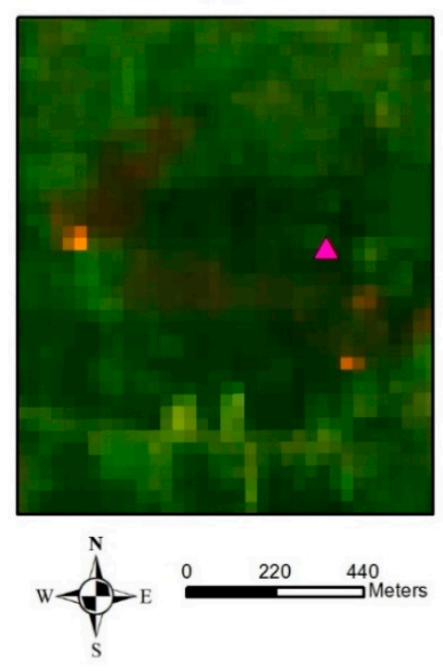

(B)

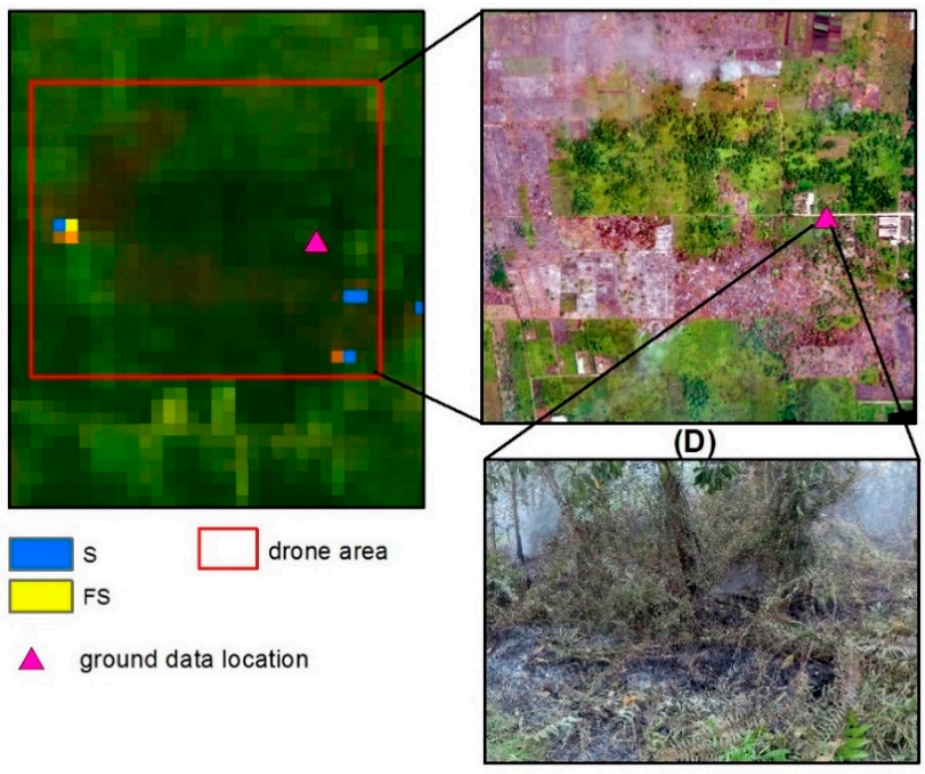

Figure 11. (A) The 764 RGB image of Landsat- 8 on 5 October 2018, presented a combustion area which was predominantly vegetated, (B) The result of peatland combustion mapping, and (C) Drone imaging and (D) Terrestrial picture of smouldering vegetation area in the area on 6 October 2018.

\subsubsection{External Validation in Riau Province}

The external validation of peatland combustion algorithm was conducted using one scene of Landsat-8 in 2016 and three scenes in 2018 in Riau Province. There were 21 ground points of fire locations which mapped well in Riau by using ToPeCAl developed in Central Kalimantan. Two examples of peatland fire with the ground truth are shown in Figure 12. One large peatland fire, which contained three classes of peat fires (S, F, FS), is shown in Figure 12A-C, with a helicopter picture (Figure 12C) taken on the same day as the Landsat-8 acquisition (20 August 2016). The second example, which is classified as smouldering fire, shows peat fire surrounded by cloud cover captured by Landsat- 8 on 4 April 2018, (Figure 12D and E). Figure 12F shows smoky conditions taken from terrestrial and helicopter cameras. 
(A)

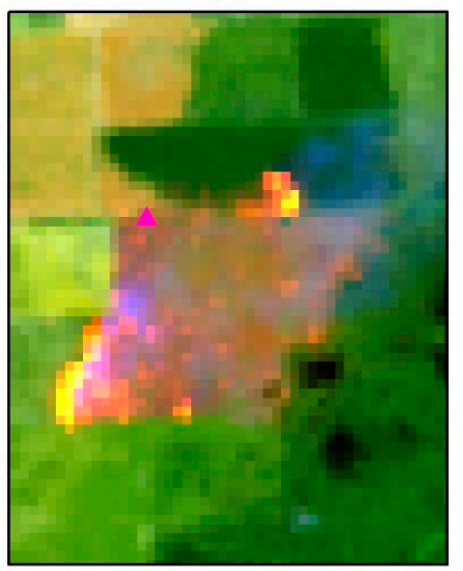

$\overbrace{S}^{N}=\mathrm{E}$

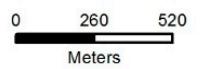

(D)



(B)



$\Delta$ ground data location

(C)



(E)

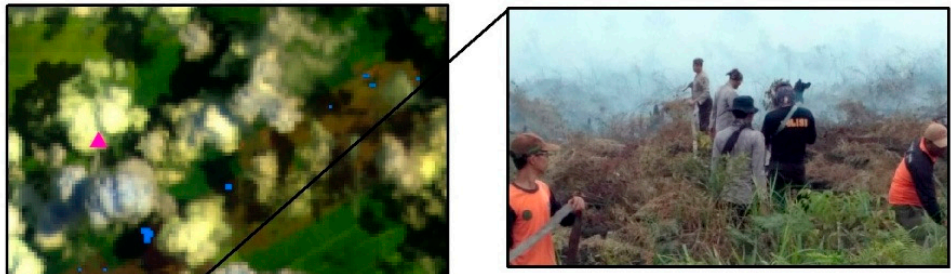

Figure 12. (A,B) The 764 RGB image of Landsat- 8 on 20 August 2016 showing a combustion area with the result of peatland combustion mapping and (C) a helicopter oblique picture taken on the same day taken in Riau Province; (D,E) The 764 RGB Image of Landsat-8 on 4 April 2018 and the result of peatland combustion mapping with ground truth location marked in red square. The pictures (F) of peatland fires from the ground and helicopter; sourced from local BNPB of Riau Province on 4 April 2018.

\subsubsection{Statistical Assessment of Tropical Peatland Combustion Algorithm Validation}

There was a total of 122 areas of observation collected from the ground for validation in Central Kalimantan and Riau Provinces; these consisted of 103 areas of peatland combustion and 19 areas of non-combustion. The 103 combustion areas from the application of ToPeCAl comprised 44 areas of smouldering (S), 26 areas of a mixture of flaming and smouldering (FS) and 16 areas of flaming (F) stages. Additionally, two combustion areas were mixed, classified as flaming and mixture of smouldering and flaming areas and 15 smouldering areas were not identified by the ToPeCAl algorithm in the non-combustion area. The 19 non-combustion areas (Non) consisted of reeds, urban/settlement, bright objects and burnt areas. Five of the 19 non-combustion areas, which were bright roofs tops, were falsely classified as a mixture of smouldering and flaming, but 14 of them were well classified 
as non-combustion areas. The summary of the field observation versus ToPeCAl is shown in the Contingency Table (Table 6A). Meanwhile, the score results based on Contingency Table of ground truth versus ToPeCAl are presented in Table 6B. This shows the overall PC of ToPeCAl mapping is $82 \%$ for three categories (S, FS, and F). For smouldering mapping, the FAR is low with a POD of 73\% and underestimated detection shown by the low BIAS. The mixture of flaming and smouldering mapping had a FAR of $16 \%$ and high POD with a low overestimated detection. Flaming mapping was quite good, with low FAR, high POD and low overestimated detection. The non-combustion areas (Non) mapping had a $48 \%$ FAR and 74\% POD with a low overestimated detection. The underestimated detection, or omission error, of smouldering mostly occurred in the urban areas and in forest areas where there was a mixture (over a $30 \mathrm{~m}$ pixel) with vegetation and half dead vegetation. The overestimated detection of FS occurred in the non-combustion areas on bright building rooftops. Masking the urban area upgraded the percentage of correct mapping from $82 \%$ up to $93 \%$.

Table 6. (A) The results of Contingency Table of ToPeCAl validation in Central Kalimantan and Riau Province (data in table shows counts), and (B) the scores of PC, FAR, POD, and BIAS of ToPeCAl Mapping compared with ground truth data.

(A)

\begin{tabular}{|c|c|c|c|c|c|c|}
\hline & & \multicolumn{4}{|c|}{ ToPeCAl Mapping Counts } & \multirow[t]{2}{*}{ Total } \\
\hline \multirow{5}{*}{ Ground truth } & Categories & $S$ & FS & $\mathrm{F}$ & Non & \\
\hline & $S$ & 44 & 1 & 0 & 15 & 60 \\
\hline & FS & 0 & 26 & 1 & 0 & 27 \\
\hline & $\mathrm{F}$ & 0 & 0 & 16 & 0 & 16 \\
\hline & Non & 0 & 5 & 0 & 14 & 19 \\
\hline \multicolumn{2}{|c|}{ Total } & 44 & 32 & 17 & 29 & 122 \\
\hline \multicolumn{7}{|c|}{ (B) } \\
\hline \multirow{2}{*}{\multicolumn{2}{|c|}{ ToPeCAl Mapping }} & \multicolumn{5}{|c|}{ SCORES } \\
\hline & & \multicolumn{2}{|c|}{ PC } & FAR & POD & BIAS \\
\hline S & & & & $0 \%$ & $73 \%$ & 0.73 \\
\hline FS & & \multirow{2}{*}{\multicolumn{2}{|c|}{$82 \%$}} & $16 \%$ & $96 \%$ & 1.19 \\
\hline $\mathrm{F}$ & & & & $0 \%$ & $100 \%$ & 1.06 \\
\hline \multicolumn{2}{|c|}{ Non } & & & $48 \%$ & $74 \%$ & 1.53 \\
\hline
\end{tabular}

3.3.4. Statistical Assessment of the $375 \mathrm{~m}$ Visible Infrared Imaging Radiometer Suite Active Fire Validation

From the total of 122 ground truth data collected in Central Kalimantan and Riau Province, there were 73 hits, 15 misses, 20 false alarms and 14 correct negatives (Table 7A). The calculation of PC resulted in $71 \%$ with a FAR of $22 \%$. The POD of fire was $83 \%$, and the BIAS was 1.05 which refers to overestimated mapping (Table 7B).

In comparison with ToPeCAl results, the PC scores were high which derived more from the higher correct negative hits than the correct positive hits. The FAR scores were also high because many of VNP14IMG existed while ToPeCAl did not exist. Table 8 shows the POD of VNP14IMG compared with ToPeCAl tends to rise with the increasing of buffer zone which could be caused by the geometric error of the VNP14IMG point location, which is automatically assigned to the center of a pixel, even if the true fire is located in the edge of pixel, for example. Using VNP14IMG data during only day-time (5:30 UTC) resulted in a lower value of POD than the combined day-time (5:30 UTC) and night time (18:12 UTC). About 72\% of ToPeCAl can be detected by VNP14IMG using combination of day-time (+ 3 hours) and night-time data (+16 hours) within a $1.5 \mathrm{~km}$ distance from the VNP14IMG points. The BIAS of VNP14IMG compared with ToPeCAl results shows significant overestimation in mapping. The greater the distance from original point of VNP14IMG, the greater the BIAS. 
Table 7. (A) The results of the Contingency Table of VNP14IMG versus ground truth in Central Kalimantan and Riau Provinces (data in table show counts), and (B) the scores of PC, FAR, POD, and BIAS of VNP14IMG compared with ground truth data.

\begin{tabular}{|c|c|c|c|c|}
\hline \multicolumn{5}{|c|}{ (A) } \\
\hline & & \multicolumn{2}{|c|}{ VNP14IMG } & \multirow{2}{*}{ Total } \\
\hline \multirow{3}{*}{ Ground truth } & Categories & Yes-Fire & No-Fire & \\
\hline & Yes-Fire & 73 & 15 & 88 \\
\hline & No-Fire & 20 & 14 & 34 \\
\hline \multicolumn{2}{|c|}{ Total } & 93 & 29 & 122 \\
\hline \multicolumn{5}{|c|}{ (B) } \\
\hline \multirow{2}{*}{ VNP14IMG } & \multicolumn{4}{|c|}{ SCORES } \\
\hline & PC & FAR & POD & BIAS \\
\hline Yes-Fire & \multirow{2}{*}{$71 \%$} & $22 \%$ & $83 \%$ & 1.05 \\
\hline No-Fire & & $48 \%$ & $41 \%$ & 0.85 \\
\hline
\end{tabular}

Table 8. (A) The scores of PC, FAR, POD, and BIAS of VNP14IMG compared with ToPeCAl with a different time of 3 hours in day-time, and (B) a combination of 3 hour and 15 hours difference in time. The calculations were generated for buffer zones of $187.5 \mathrm{~m}$ to $1250 \mathrm{~m}$.

\begin{tabular}{ccccc}
\hline \multicolumn{5}{c}{ (A) } \\
\hline Buffer Zone (m) & PC & FAR & POD & BIAS \\
\hline 187.5 & $99.9 \%$ & $94.3 \%$ & $6 \%$ & 1.1 \\
375 & $99.8 \%$ & $95.9 \%$ & $19 \%$ & 4.7 \\
500 & $99.8 \%$ & $96.2 \%$ & $21 \%$ & 5.3 \\
750 & $97.7 \%$ & $97.7 \%$ & $29 \%$ & 12.8 \\
1000 & $99.2 \%$ & $98.3 \%$ & $33 \%$ & 19.6 \\
1250 & $98.9 \%$ & $98.7 \%$ & $37 \%$ & 27.5 \\
1500 & $98.5 \%$ & $98.8 \%$ & $42 \%$ & 35.7 \\
\hline \multicolumn{5}{c}{$\mathbf{( B )}$} \\
Buffer Zone (m) & PC & FAR & POD & BIAS \\
\hline 187.5 & $99.9 \%$ & $91.7 \%$ & $23 \%$ & 2.8 \\
375 & $99.7 \%$ & $92.8 \%$ & $57 \%$ & 8.0 \\
500 & $99.6 \%$ & $94.4 \%$ & $62 \%$ & 11.0 \\
750 & $99.4 \%$ & $96.3 \%$ & $66 \%$ & 17.8 \\
1000 & $99.1 \%$ & $97.3 \%$ & $69 \%$ & 25.4 \\
1250 & $98.8 \%$ & $97.9 \%$ & $70 \%$ & 33.9 \\
1500 & $98.5 \%$ & $98.3 \%$ & $72 \%$ & 43.0 \\
\hline
\end{tabular}

In order to know which parts of peatland combustion were dominantly detected by VNP14IMG, the comparison was conducted for all combustion stages of ToPeCAl, which consisted of 14,157 pixels of $S, 3173$ pixels of FS, and 3815 pixels of $F$ with the combination of VNP14IMG at 5:30 UTC and 18:12 UTC. The results of POD of S, FS, and F were plotted against the buffer zone distances as shown in Figure 13. There were a significant increase in POD rising from a distance of $187.5 \mathrm{~m}$ to $375 \mathrm{~m}$ of VNP14IMG points. The highest portion of ToPeCAl detected by VNP14IMG shown by POD scores corresponded to flaming combustion, starting from the zone of $375 \mathrm{~m}$, at about $80 \%$ to $83 \%$ in the zone of $1500 \mathrm{~m}$. Meanwhile, the portion of smouldering detected was about $50 \%$ at $375 \mathrm{~m}$ then rising to $70 \%$ at $1500 \mathrm{~m}$. The POD for a mixture of flaming and smouldering was about $60 \%$ from $375-1500 \mathrm{~m}$. 


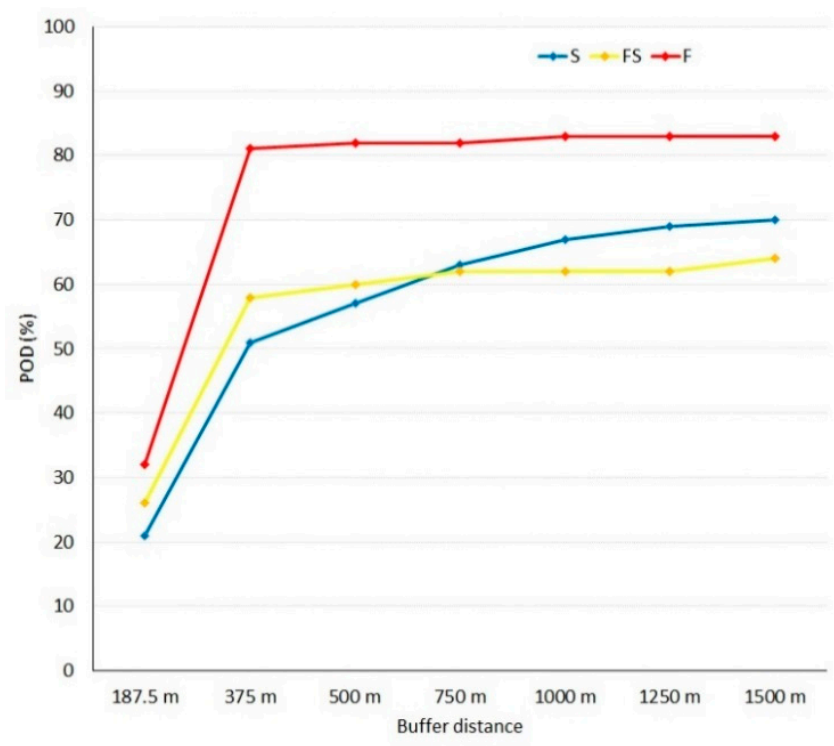

Figure 13. POD of peatland combustion (S, FS, and F) detected by VNP14IMG from day-time and night-time data in buffered zones of $187.5 \mathrm{~m}$ to $1500 \mathrm{~m}$.

\section{Discussion}

ToPeCAl was developed to detect flaming and smouldering peat fire in clear sky and smoky atmospheric conditions using day-time images of Landsat- 8 . The TIR- 1 band was used along with SWIR-2 band to strengthen the detection of smouldering peat fire. ToPeCAl was developed in Central Kalimantan peatland from the Landsat- 8 data acquired during the 2015 fire period, was tested on different acquisition days and also outside the development area in Riau, Sumatera Island. The recent fire algorithm, GOLI, takes advantage of the reflectance of SWIR (SWIR-1 and SWIR-2) and the visible red bands of Landsat-8. However, GOLI did not perform well on smouldering peatland fire [42]. Here, ToPeCAl was compared with GOLI in one peatland combustion area in Central Kalimantan on September 28, 2018, and it was found that ToPeCAl generated a better detection on smouldering fire than GOLI. The fire product in GOLI is termed "active fire" [42]. The consideration of using a suitable and consistent term to determine which part of a fire stage (smouldering, flaming, etc.) which is dominantly detected by a specific algorithm applied to a satellite sensor needs greater attention. Many previous researchers $[3,15,39,42]$ use the "active fire" term derived from different sensors with different spectra. For example, in low spatial resolution data, MODIS and VIIRS, the fire product is based on middle infrared/MIR $(3-4 \mu \mathrm{m})$ and TIR $(10-12 \mu \mathrm{m})$, and the product is termed "active fire" [3,15]. Meanwhile for medium spatial resolution such as Landsat-8, in which MIR does not exist, the fire detection is generated from SWIR, and some researchers label the fire product as "active fire" [39,42] or "hot target for fire" or "lava flow" [29]. In the middle infrared, fire objects, even with low temperatures (e.g., smouldering) can emit radiance at two orders (100 times) of magnitude greater than background, while in thermal infrared radiance can be one order (10 times) of magnitude higher than non-burning surfaces [34]. Meanwhile, according to the Wien displacement law, higher temperatures, such as flaming fire, are better observed at the shorter wavelengths, while the lower temperature fire, such as smouldering, is better observed at longer spectral wavelengths. This supports the logic that the SWIR is advantageous in detecting flaming rather than smouldering, while the MIR is better for flaming and smouldering detection than TIR. In case the MIR does not exist in a sensor then TIR is better to detect smouldering than SWIR.

During day-time, atmospheric disturbances in the tropics, as well as smoky condition from smouldering fires, can affect the detection of smouldering peatland. Thus, ToPeCAl introduces an adjustment of SWIR-2 and TIR-1 thresholds for flaming and smouldering detection based on atmospheric conditions. The effect of smoke on the detectability of objects was described in Section 2.4, 
which shows lower brightness temperatures of TIR-1 over various non combustion and combustion areas, compared to those in clear sky conditions; this concurs with [53] who write that smoke has a cooling effect on the atmosphere. In some pixels around the flaming or smouldering pixels, we found that not all combustion pixels were mapped due to heavy smoke obscuration. This suggests that further smoke detection and analysis research is required to enhance ToPeCAl. The use of aerosol band of Landsat-8 for smoke property detection still lacks research; perhaps multiband techniques can be utilised to better characterise smoke in more quantitative ways or perhaps other satellites, which focus on atmospheric properties, can be combined with Landsat to improve this aspect of ToPeCAl?

Previous research on fire detection from medium spatial resolution satellite data reports that bright objects, especially high reflective rooftops, have been a consistent source of commission errors due to high day-time radiance in SWIR wavelengths $[29,39,42]$. Thresholds in SWIR spectrum at $2.2 \mu \mathrm{m}$ were used to eliminate the bright rooftops, and even with the use of NDVI from the period immediately prior to the fire detection, the bright rooftops still existed [29,39,42]. In this study, the advantages of SWIR were also used for non-combustion masking, but we also generated the ratio of SWIR-2 and SWIR-1 reflectance, $\mathrm{SICI}_{\rho}$, with a threshold from its median value to separate combustion areas from non-combustion areas (burnt area, urban, plantation, forest, urban, mining, water, and cloud). However, over very high reflective building rooftops, we still experienced the same problem as other previous researches. Thus, to finalise the ToPeCAl, a GIS was used to mask urban areas, as recommended by previous researches [39,42]. In Indonesia, the landuse map is updated yearly by the Ministry of Forestry using multi-temporal images of Landsat- 8 data, with a reference to high spatial resolution such as SPOT-6/7 provided by LAPAN. The scale of the landuse map is 1:50.000 with the smallest pixel size of 6.25 ha or similar to $250 \mathrm{~m}$ pixel resolution. In this case, the masking of settlements or urban areas, which have a dominance of high reflective rooftops, will potentially introduce omission errors of peatland combustion detection in the urban area. However, the local disaster management agency has a good social network in the community and if a fire occurs in the urban area, it will be first solved by the authority due to the fast information given from residents, as the people's safety is the priority for the firefighters. Another problem of using the urban GIS, especially at 1:50,000 scale, is the limitation of mapping a small individual building or small groups of buildings with bright rooftops. These will potentially still be detected as false positives.

The ground validation of forest/peatland fire is relatively difficult, compared with other ground surveys for remote sensing applications. Ideally, the ground truth is collected at the same time of satellite overpass of the fire area. However, the optical satellite image of fire occurrence in tropical areas can be interrupted by cloud cover and smoke. Thus, if a perfect time for observation of both ground truth and satellite image is not available, then ground truth often may not temporally coincide with satellite observations. However, because peatland fire spread rates are slow, ground truth collected one week before or after the satellite image acquisition still can be used for validation, particularly with significant support information from local histories of a particular fire occurrence in a certain area. Other than that, there is a problem in obtaining precise ground fire locations in tropical peatland environment if the accessibility is limited. For example, there were some significant large peatland fires on the day of ground survey on 28 September 2018, which coincided with a Landsat-8 pass over the area. However, the locations of peat fires were in deeply forested peatland, which could not be reached by road transportation, and forced ground crews to use small boats on rivers and canals and then continue walking for about $1-4 \mathrm{~km}$. To compensate for this limited accessibility, the ground truth in some locations was collected by drone or helicopter imaging, often using oblique image orientations to avoid direct flight over fire. These conditions lead to manual choice of points for validation of ToPeCAl.

The performance of ToPeCAl to ground truth was statistically analysed with the Yes and No scores presented in the contingency table (Table 6). Over internal (Central Kalimantan) and external (Riau) validation areas, ToPeCAl had a correct mapping of $82 \%$, with omission an error of $27 \%$ for small smouldering fires. About 15 locations of the 103 combustion areas were not classified as smouldering fires. The 15 smouldering fires found in the field were mostly small in size (far less 
than one Landsat pixel) and located in areas immediately adjacent to healthy vegetation or half dead vegetation. According to [41], the detection of smouldering fires using night-time data also was limited to $40-90 \mathrm{~m}^{2}$, corresponding to some of the small smouldering peat fires found in urban areas. The limitation in detecting small smouldering fires can also be partially attributed to the fact that the original spatial resolution of TIR is $100 \mathrm{~m}$ while the SWIR is $30 \mathrm{~m}$.

A preliminary analysis for comparing the $375 \mathrm{~m}$ VIIRS active fire product (VNP14IMG) with ToPeCAl was conducted in this study. This analysis was done based on the idea of introducing image/data fusion to obtain high spatial and high temporal resolution for peatland combustion monitoring. The VNP14IMG was quite good when compared with ground truth with $71 \%$ PC and a BIAS score of 1.05, which represents a slight overestimation. Compared with ToPeCAl results from Landsat-8, the VNP14IMG gave a high (>90\%) PC when utilising a buffer zone for the comparison. However, the FAR was quite high $(>90 \%)$ which infers over detection of fire by the VIIRS product compared with ToPeCAl. A low POD (<30\%) existed when using day-time data alone, even though it was close in time ( +3 hours) to the Landsat -8 acquisition. By combining the day-time data ( +3 hours from Landsat-8) and the night-time data (+16 hours from Landsat-8), a higher POD was obtained of about $57 \%$ (375 $\mathrm{m}$ buffer zone) and up to $72 \%$ (1.5 km buffer zone). This due to a higher correct positive and lower false positive fire pixels detected with night-time data, with POD about of $49 \%$ (375 $\mathrm{m}$ buffer zone) to $69 \%$ (1.5 km buffer zone). The highest portion of POD when using the combined VNP14IMG (+3 and +16 hours) in detecting peatland combustion stages from ToPeCAl applied to Landsat-8 was on the flaming stage ( $~ 80 \%)$, while the smouldering stage was about $60 \%$. Overall, the BIAS showed that the VNP14IMG product overestimated detection of fire and that this increased with buffer zone size compared with ToPeCAl results. A further investigation needs to be conducted to check the problem of omission and commission error of VNP14IMG product over peatland area before fusion of fire information with Landsat- 8 is instituted. A better POD might be achieved by combining the day-time (+3 hours), night-time (+16 hours), and the previous data of VNP14IMG at night-time which at about -8 hours different from Landsat- 8 .

The tropical peatland combustion algorithm from day-time Landsat- 8 data can be potentially operationalised in Indonesia by LAPAN as mandated by the government as the national satellite data provider of mapping of forest fires including peatland fire. This fire information is delivered to the BNPB as the agency who use the fire information for extinguishment support. In order to fill the temporal gaps between Landsat- overpasses, further research into the VNP14IMG product is needed. As peatland fire detection requires a high spatial resolution, the use of Sentinel-2 sensors with a higher temporal resolution (5 days) than Landsat, a $20 \mathrm{~m}$ spatial resolution and the same SWIR spectra in $2.2 \mu \mathrm{m}$, but without TIR spectra, could be explored, but with an adjustment for lack of a TIR spectra.

\section{Conclusions}

The discrimination of flaming and smouldering combustion of peatland fires over tropical areas can be mapped through the use of day-time images from Landsat-8. ToPeCAl consists of the $\mathrm{SICI}_{\rho}$ for separating combustion from the non-combustion areas, TOA planetary reflectance of SWIR-2 $(2.2 \mu \mathrm{m})$, and TOA brightness temperature of TIR-1 $(10.9 \mu \mathrm{m})$ for classifying the peatland combustion into flaming and smouldering stages. The overall accuracy of peatland combustion mapping is $82 \%$, with omission errors in small areas corresponding to smouldering mixed with green vegetation. Commission errors relate to bright building rooftops, which can be eliminated by urban area masking with landuse data and leads to a higher accuracy up to $93 \%$.

The operationalisation of the peatland combustion algorithm for providing peatland fire information is possible for the whole Indonesian archipelago, including other tropical peatland area such as Malaysia, though clearly the issue of cloud obscuration needs overcoming. There is a possibility to merge the Landsat-8 results on peatland combustion mapping with other satellite sensors such as the $375 \mathrm{~m}$ VIIRS active fire product (VNP14IMG) for the supply of daily information. The preliminary assessment of the VNP14IMG (+3 and +16 hours from Landsat-8) data provided a 57-72\% probability 
of detection of fire compared with ToPeCAl results of Landsat-8 in 375-1500 m zones. The VNP14IMG product at night-time provides a better probability of detection compared with ToPeCAl results than day-time data. These need further investigation. Other than VNP14IMG, Sentinel-2 images with higher spatial resolution $(20 \mathrm{~m}$ ) and a repeat cycle ( 5 days) could also be explored for enhancing peatland fire detection for small smouldering fires.

Author Contributions: The research was designed and conceptualised by P.S., D.B., E.J., and J.M. Data analysis by P.S., D.B., and E.J. Principal Supervision by D.B. Paper writing by P.S with review and editorial advice from all co-authors.

Funding: This research was funded by the Research and Innovation in Science and Technology Project (RISET-Pro) World Bank Loan No. 8245-ID, Ministry of Research, Technology and Higher Education of the Republic of Indonesia (Kemenristekdikti) and the University of South Australia (UniSA) school of Natural and Built Environments.

Acknowledgments: We would like to acknowledge the Remote Sensing Application Center of Indonesian National Institute of Aeronautics and Space (LAPAN) and Disaster Management Agency (BNPB) of Central Kalimantan and Riau Provinces for supporting ground truth collection. We also would like to thank the reviewers for their constructive comments on our manuscript.

Conflicts of Interest: The authors declare no conflict of interest. The funders had no role in the design of the study; in the collection, analyses, or interpretation of data; in the writing of the manuscript, or in the decision to publish the results.

\section{Appendix A}

Table A1. Spectral properties of Landsat- 8 OLI and TIRS [55,60,61]. The radiance and temperature values are at sensor at the Top of Atmosphere (TOA). The TOA temperature is only measured in TIR bands.

\begin{tabular}{|c|c|c|c|c|}
\hline \multirow[b]{2}{*}{ Band Name } & \multirow{2}{*}{$\begin{array}{l}\text { Band Width } \\
(\mu \mathrm{m})\end{array}$} & \multirow{2}{*}{$\begin{array}{c}\text { Center } \\
\text { Wavelength }(\mu \mathrm{m})\end{array}$} & \multicolumn{2}{|c|}{ Saturation } \\
\hline & & & $\begin{array}{c}\text { Radiance } \\
\left(\mathrm{Wm}^{-2} \mathrm{sr}^{-1} \mu \mathrm{m}^{-1}\right)\end{array}$ & Temperature (K) \\
\hline $\begin{array}{c}\text { Band-1: } \\
\text { coastal/aerosol }\end{array}$ & $0.435-0.451$ & 0.443 & 950 & - \\
\hline Band-2: blue & $0.452-0.512$ & 0.482 & 800 & - \\
\hline Band-3: green & $0.533-0.590$ & 0.561 & 760 & - \\
\hline Band-4: red & $0.636-0.673$ & 0.655 & 740 & - \\
\hline Band-5: NIR & $0.851-0.879$ & 0.865 & 500 & - \\
\hline Band-6: SWIR-1 & $1.566-1.651$ & 1.609 & 96 & - \\
\hline Band-7: SWIR-2 & $2.107-2.294$ & 2.201 & 29 & - \\
\hline Band-10: TIR-1 & 10.61-11.19 & 10.9 & 20.5 & 360 \\
\hline Band-11: TIR-2 & $11.50-12.51$ & 12.0 & 17.8 & 360 \\
\hline
\end{tabular}

\section{References}

1. Justice, C.; Giglio, L.; Korontzi, S.; Owens, J.; Morisette, J.; Roy, D.; Descloitres, J.; Alleaume, S.; Petitcolin, F.; Kaufman, Y. The MODIS fire products. Remote Sens. Environ. 2002, 83, 244-262. [CrossRef]

2. Csiszar, I.; Schroeder, W.; Giglio, L.; Ellicott, E.; Vadrevu, K.P.; Justice, C.O.; Wind, B. Active fires from the Suomi NPP visible infrared imaging radiometer suite: Product status and first evaluation results. J. Geophys. Res. Atmos. 2014, 119, 803-816. [CrossRef]

3. Giglio, L.; Schroeder, W.; Justice, C. The collection 6 MODIS active fire detection algorithm and fire products. Remote Sens. Environ. 2016, 178, 31-41. [CrossRef] [PubMed]

4. Page, S.E.; Rieley, J.; Banks, C. Global and regional importance of the tropical peatland carbon pool. Glob. Chang. Biol. 2011, 17, 798-818. [CrossRef]

5. Rieley, J.; Page, S. Tropical Peatland of the World; Springer: Tokyo, Japan, 2016.

6. Osaki, M.; Nursyamsi, D.; Noor, M.; Wahyunto; Segah, H. Peatland in Indonesia. In Tropical Peatland Ecosystems, 1st ed.; Osaki, M., Tsuji, N., Eds.; Springer: Tokyo, Japan, 2016; pp. 49-58.

7. Tacconi, L. Fires in Indonesia: Causes, Costs and Policy Implications; CIFOR: Bogor, Indonesia, 2003. 
8. World-Bank. The Cost of Fire: An Economic Analysis of Indonesia's 2015 Fire Crisis; World Bank Group: Jakarta, Indonesia, 2016. Available online: http:/ / pubdocs.worldbank.org/en/643781465442350600/Indonesiaforest-fire-notes.pdf (accessed on 8 April 2017).

9. Purnomo, H.; Shantiko, B.; Sitorus, S.; Gunawan, H.; Achdiawan, R.; Kartodihardjo, H.; Dewayani, A.A. Fire economy and actor network of forest and land fires in Indonesia. For. Policy Econ. 2017, 78, $21-31$. [CrossRef]

10. Xu, W.; Wooster, M.J.; Roberts, G.; Freeborn, P. New GOES imager algorithms for cloud and active fire detection and fire radiative power assessment across north, south and central America. Remote Sens. Environ. 2010, 114, 1876-1895. [CrossRef]

11. Filizzola, C.; Corrado, R.; Marchese, F.; Mazzeo, G.; Paciello, R.; Pergola, N.; Tramutoli, V. RST-fires, an exportable algorithm for early-fire detection and monitoring: Description, implementation, and field validation in the case of the MSG-SEVIRI sensor. Remote Sens. Environ. 2016, 186, 196-216. [CrossRef]

12. Fuller, D.O. Satellite remote sensing of biomass burning with optical and thermal sensors. Prog. Phys. Geogr. 2000, 24, 543-561. [CrossRef]

13. Langner, A.; Siegert, F. Spatiotemporal fire occurrence in Borneo over a period of 10 years. Glob. Chang. Biol. 2009, 15, 48-62. [CrossRef]

14. Caúla, R.H.; Oliveira-Júnior, J.F.; Lyra, G.B.; Delgado, R.C.; Heilbron Filho, P.F.L. Overview of fire foci causes and locations in Brazil based on meteorological satellite data from 1998 to 2011. Environ. Earth Sci. 2015, 74, 1497-1508. [CrossRef]

15. Schroeder, W.; Oliva, P.; Giglio, L.; Csiszar, I. The new VIIRS $375 \mathrm{~m}$ active fire detection data product: Algorithm description and initial assessment. Remote Sens. Environ. 2014, 143, 85-96. [CrossRef]

16. Hally, B.; Wallace, L.; Reinke, K.; Jones, S. Assessment of the utility of the advanced Himawari imager to detect active fire over Australia. Int. Arch. Photogramm. Remote Sens. Spat. Inf. Sci. ISPRS Arch. 2016, 41, 65-71. [CrossRef]

17. BNPB; Central Kalimantan Province, Indonesia. Personal Communication, 2018.

18. Rein, G. Smoldering combustion. In SFPE Handbook of Fire Protection Engineering; Springer: New York, NY, USA, 2016; pp. 581-603.

19. Hawbaker, T.J.; Radeloff, V.C.; Syphard, A.D.; Zhu, Z.; Stewart, S.I. Detection rates of the modis active fire product in the United States. Remote Sens Environ. 2008, 112, 2656-2664. [CrossRef]

20. Hantson, S.; Padilla, M.; Corti, D.; Chuvieco, E. Strengths and weaknesses of modis hotspots to characterize global fire occurrence. Remote Sens Environ. 2013, 131, 152-159. [CrossRef]

21. Loboda, T.V.; Csiszar, I.A. Reconstruction of fire spread within wildland fire events in northern Eurasia from the MODIS active fire product. Glob. Planet. Chang. 2007, 56, 258-273. [CrossRef]

22. Jones, S.; Hally, B.; Reinke, K.; Wickramasinghe, C.; Wallace, L.; Engel, C. Next Generation Fire Detection from Geostationary Satellites. In Proceedings of the IGARSS 2018-2018 IEEE International Geoscience and Remote Sensing Symposium, Valencia, Spain, 22-27 July 2018; pp. 5465-5468.

23. Rein, G. Smouldering fires and natural fuels. In Fire Phenomena and the Earth System: An Interdisciplinary Guide to Fire Science; Belcher, Ed.; Wiley and Sons: Hoboken, NJ, USA, 2013; Chapter 2; pp. 13-22.

24. Zaccone, C.; Rein, G.; D'Orazio, V.; Hadden, R.M.; Belcher, C.M.; Miano, T.M. Smouldering fire signatures in peat and their implications for palaeoenvironmental reconstructions. Geochim. Cosmochim. Acta 2014, 137, 134-146. [CrossRef]

25. Koppmann, R.; von Czapiewski, K.; Reid, J.S. A review of biomass burning emissions, part I: Gaseous emissions of carbon monoxide, methane, volatile organic compounds, and nitrogen containing compounds. Atmos. Chem. Phys. Discuss. 2005, 5, 10455-10516. [CrossRef]

26. Reid, J.S.; Koppmann, R.; Eck, T.F.; Eleuterio, D.P. A review of biomass burning emissions part II: Intensive physical properties of biomass burning particles. Atmos. Chem. Phys. 2005, 5, 799-825. [CrossRef]

27. Giglio, L.; Kendall, J.D. Application of the dozier retrieval to wildfire characterization: A sensitivity analysis. Remote Sens Environ. 2001, 77, 34-49. [CrossRef]

28. Kelhä, V.; Rauste, Y.; Häme, T.; Sephton, T.; Buongiorno, A.; Frauenberger, O.; Soini, K.; Venäläinen, A.; Miguel-Ayanz, J.S.; Vainio, T. Combining AVHRR and ATSR satellite sensor data for operational boreal forest fire detection. Int. J. Remote Sens. 2003, 24, 1691-1708. [CrossRef]

29. Murphy, S.W.; de Souza Filho, C.R.; Wright, R.; Sabatino, G.; Correa Pabon, R. Hotmap: Global hot target detection at moderate spatial resolution. Remote Sens. Environ. 2016, 177, 78-88. [CrossRef] 
30. Siegert, F.; Zhukov, B.; Oertel, D.; Limin, S.; Page, S.E.; Rieley, J.O. Peat fires detected by the BIRD satellite. Int. J. Remote Sens. 2004, 25, 3221-3230. [CrossRef]

31. Mitchell, S.; Jones, S.; Reinke, K.; Lorenz, E.; Reulke, R. Assessing the utility of the TET-1 hotspot detection and characterization algorithm for determining wildfire size and temperature. Int. J. Remote Sens. 2016, 37, 4731-4747. [CrossRef]

32. Atwood, E.; Englhart, S.; Lorenz, E.; Halle, W.; Wiedemann, W.; Siegert, F. Detection and characterization of low temperature peat fires during the 2015 fire catastrophe in indonesia using a new high-sensitivity fire monitoring satellite sensor (FireBird). PLOS ONE 2016, 11, 1-24. [CrossRef] [PubMed]

33. Eckmann, T.; Roberts, D.; Still, C. Estimating subpixel fire sizes and temperatures from aster using multiple endmember spectral mixture analysis. Int. J. Remote Sens. 2009, 30, 5851-5864. [CrossRef]

34. Giglio, L.; Csiszar, I.; Restás, Á.; Morisette, J.T.; Schroeder, W.; Morton, D.; Justice, C.O. Active fire detection and characterization with the advanced spaceborne thermal emission and reflection radiometer (ASTER). Remote Sens. Environ. 2008, 112, 3055-3063. [CrossRef]

35. Polivka, T.N.; Jun Wang, L.T.; Ellison, E.J.; Hyer, C.M.; Ichoku, C.M. Improving nocturnal fire detection with the VIIRS day-night band. IEEE Trans. Geosci. Remote Sens. 2016, 54, 5503-5519. [CrossRef]

36. Wooster, M.J.; Xu, W.; Nightingale, T. Sentinel-3 SLSTR active fire detection and FRP product: Pre-launch algorithm development and performance evaluation using MODIS and ASTER datasets. Remote Sens. Environ. 2012, 120, 236-254. [CrossRef]

37. Schroeder, W.; Prins, E.; Giglio, L.; Csiszar, I.; Schmidt, C.; Morisette, J.; Morton, D. Validation of GOES and MODIS active fire detection products using ASTER and ETM+ data. Remote Sens. Environ. 2008, 112, 2711-2726. [CrossRef]

38. Morisette, J.; Giglio, L.; Csiszar, I.; Justice, C. Validation of the MODIS active fire product over southern Africa with ASTER data. Int. J. Remote Sens. 2005, 26, 4239-4264. [CrossRef]

39. Schroeder, W.; Oliva, P.; Giglio, L.; Quayle, B.; Lorenz, E.; Morelli, F. Active fire detection using Landsat-8/OLI data. Remote Sens. Environ. 2016, 185, 210-220. [CrossRef]

40. Dennison, P.E.; Roberts, D.A. Daytime fire detection using airborne hyperspectral data. Remote Sens. Environ. 2009, 113, 1646-1657. [CrossRef]

41. Elvidge, C.D.; Zhizhin, M.; Hsu, F.; Baugh, K.; Khomarudin, M.; Vetrita, Y.; Sofan, P.; Suwarsono; Hilman, D. Long-wave infrared identification of smoldering peat fires in Indonesia with nighttime Landsat data. Environ. Res. Lett. 2015, 10, 065002. [CrossRef]

42. Kumar, S.S.; Roy, D.P. Global operational land imager Landsat-8 reflectance-based active fire detection algorithm. Int. J. Digit. Earth 2018, 11, 154-178. [CrossRef]

43. BPS-Statistic Central Kalimantan Province. Kalimantan Tengah in Figures 2018. Available online: https: / kalteng.bps.go.id/publication/2018/08/16/ceed046d35684aefde786f04/provinsi-kalimantantengah-dalam-angka-2018.html (accessed on 16 August 2018).

44. BPS-Statistic Indonesia. Plantation Area by Province and Crops, Indonesia (000 ha), 2012-2015. 2015. Available online: https://www.neliti.com/publications/52029/plantation-area-by-province-and-cropsindonesia-000-ha-2012-2015 (accessed on 10 December 2017).

45. Getis, A.; Ord, J.K. The analysis of spatial association by use of distance statistics. In Perspectives on Spatial Data Analysis; Springer: Berlin/Heidelberg, Germany, 1992; pp. 189-206.

46. Mitchell, A. The ESRI Guide to GIS Analysis, 1st ed.; ESRI: Redlands, CA, USA, 1999.

47. BPS-Statistic Riau Province. Riau Province in Figures 2018. Available online: https://riau.bps.go.id/ publication/2018/08/16/b3aeccc52eab08744fbd1ddf/provinsi-riau-dalam-angka-2018.html (accessed on 6 September 2018).

48. Ritung, S.; Wahyunto, N.K. Karakteristik dan sebaran lahan gambut di Sumatera, Kalimantan dan Papua. In Pengelolaan Lahan Gambut Berkelanjutan; Balai Besar Litbang SDLP: Bogor, Indonesia, 2012. (In Bahasa)

49. Sofan, P.; Bruce, D.; Jones, E.; Marsden, J. Detecting peatland combustion using shortwave and thermal infrared Landsat-8 data. In Advance Forest Fire Research; Imprensa da Universidade de Coimbra: Coimbra, Portugal, 2018; pp. 969-979.

50. Petitcolin, F.; Vermote, E. Land surface reflectance, emissivity and temperature from MODIS middle and thermal infrared data. Remote Sens. Environ. 2002, 83, 112-134. [CrossRef]

51. Nikam, B.R.; Ibragimov, F.; Chouksey, A.; Garg, V.; Aggarwal, S.P. Retrieval of land surface temperature from Landsat 8 TIRS for the command area of mula irrigation project. Environ. Earth Sci. 2016, 75, 1169. [CrossRef] 
52. Sobrino, J.A.; Jimenez-Munoz, J.C.; Soria, G.; Romaguera, M.; Guanter, L.; Moreno, J.; Plaza, A.; Martinez, P. Land surface emissivity retrieval from different VNIR and TIR sensors. IEEE Trans. Geosci. Remote Sens. 2008, 46, 316-327. [CrossRef]

53. Guillevic, P.; Göttsche, F.; Nickeson, J.; Hulley, G.; Ghent, D.; Yu, Y.; Trigo, I.; Hook, S.; Sobrino, J.A.; Remedios, J.; et al. Land Surface Temperature Product Validation Best Practice Protocol. Land Product Validation Subgroup (WGCV/CEOS). 2018. Available online: https://lpvs.gsfc.nasa.gov/PDF/CEOS_LST_ PROTOCOL_Feb2018_v1.1.0_light.pdf (accessed on 25 December 2018).

54. Marchetti, D. A physics exhibit to show the effect of the aerosol in the atmosphere on electromagnetic wave propagation. Procedia Soc. Behav. Sci. 2015, 174, 2975-2982. [CrossRef]

55. Morfitt, R.; Barsi, J.; Levy, R.; Markham, B.; Micijevic, E.; Ong, L.; Scaramuzza, P.; Vanderwerff, K. Landsat-8 operational land imager (OLI) radiometric performance on-orbit. Remote Sens. 2015, 7, 2208-2237. [CrossRef]

56. Aufaristama, M.; Hoskuldsson, A.; Jonsdottir, I.; Ulfarsson, M.O.; Thordarson, T. New insights for detecting and deriving thermal properties of lava flow using infrared satellite during 2014-2015 effusive eruption at holuhraun, iceland. Remote Sens. 2018, 10, 151. [CrossRef]

57. Stanski, H.R.; Wilson, L.J.; Burrows, W.R. Survey of Common Verification Methods in Meteorology; World Meteorological Organization: Geneva, Switzerland, 1989.

58. Stefano Mariani, M.C. Forecast Verification: A Summary of Common Approaches, and Examples of Application; University of Trento: Trento, Italy, 2008.

59. Schroeder, W. Visible Infrared Imaging Radiometer Suite (VIIRS) 375 m \& 750 m Active Fire Detection Data Sets Based on Nasa VIIRS Land Science Investigator Processing System (SIPS) Reprocessed Data-Version 1. NASA, 2017. Available online: https://pdaac.usgs.gov/sites/default/files/public/ product_documentation/vnp14_user_guide_v1.3.pdf (accessed on 12 December 2018).

60. USGS. Landsat 8 (L8) Data Users Handbook. LSDS-1574 Version 3.0 ed.; South Dakota, U.S.; 2018. Available online: https: / /landsat.usgs.gov/landsat-8-data-users-handbook (accessed on 28 November 2018).

61. Irons, J.R.; Dwyer, J.L.; Barsi, J.A. The next Landsat satellite: The Landsat data continuity mission. Remote Sens. Environ. 2012, 122, 11-21. [CrossRef]

(C) 2019 by the authors. Licensee MDPI, Basel, Switzerland. This article is an open access article distributed under the terms and conditions of the Creative Commons Attribution (CC BY) license (http://creativecommons.org/licenses/by/4.0/). 